\title{
Review
}

\section{FGF/FGFR-Dependent Molecular Mechanisms Underlying Anti-Cancer Drug Resistance}

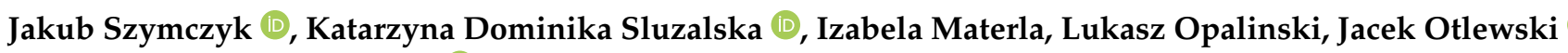 \\ and Malgorzata Zakrzewska * $\mathbb{D}$
}

\begin{abstract}
Department of Protein Engineering, Faculty of Biotechnology, University of Wroclaw, Ul. F. Joliot-Curie 14a, 50-383 Wroclaw, Poland; jakub.szymczyk@uwr.edu.pl (J.S.); katarzyna.sluzalska@uwr.edu.pl (K.D.S.); zmaterla12@gmail.com (I.M.); lukasz.opalinski@uwr.edu.pl (L.O.); jacek.otlewski@uwr.edu.pl (J.O.)

* Correspondence: malgorzata.zakrzewska@uwr.edu.pl; Tel.: +48-713752889
\end{abstract}

\section{check for}

updates

Citation: Szymczyk, J.; Sluzalska, K.D.; Materla, I.; Opalinski, L.; Otlewski, J.; Zakrzewska, M. FGF/FGFR-Dependent Molecular Mechanisms Underlying Anti-Cancer Drug Resistance. Cancers 2021, 13, 5796. https://doi.org/10.3390/ cancers 13225796

Academic Editors: Elisabetta Ferretti, A. Rughetti and Zein Mersini Besharat

Received: 26 October 2021

Accepted: 16 November 2021

Published: 18 November 2021

Publisher's Note: MDPI stays neutral with regard to jurisdictional claims in published maps and institutional affiliations.

Copyright: (c) 2021 by the authors. Licensee MDPI, Basel, Switzerland. This article is an open access article distributed under the terms and conditions of the Creative Commons Attribution (CC BY) license (https:/ / creativecommons.org/licenses/by/ $4.0 /)$.
Simple Summary: Deregulation of the FGF/FGFR axis is associated with many types of cancer and contributes to the development of chemoresistance, limiting the effectiveness of current treatment strategies. There are several mechanisms involved in this phenomenon, including cross-talks with other signaling pathways, avoidance of apoptosis, stimulation of angiogenesis, and initiation of EMT. Here, we provide an overview of current research and approaches focusing on targeting components of the FGFR/FGF signaling module to overcome drug resistance during anti-cancer therapy.

Abstract: Increased expression of both FGF proteins and their receptors observed in many cancers is often associated with the development of chemoresistance, limiting the effectiveness of currently used anti-cancer therapies. Malfunctioning of the FGF/FGFR axis in cancer cells generates a number of molecular mechanisms that may affect the sensitivity of tumors to the applied drugs. Of key importance is the deregulation of cell signaling, which can lead to increased cell proliferation, survival, and motility, and ultimately to malignancy. Signaling pathways activated by FGFRs inhibit apoptosis, reducing the cytotoxic effect of some anti-cancer drugs. FGFRs-dependent signaling may also initiate angiogenesis and EMT, which facilitates metastasis and also correlates with drug resistance. Therefore, treatment strategies based on FGF/FGFR inhibition (using receptor inhibitors, ligand traps, monoclonal antibodies, or microRNAs) appear to be extremely promising. However, this approach may lead to further development of resistance through acquisition of specific mutations, metabolism switching, and molecular cross-talks. This review brings together information on the mechanisms underlying the involvement of the FGF/FGFR axis in the generation of drug resistance in cancer and highlights the need for further research to overcome this serious problem with novel therapeutic strategies.

Keywords: FGF; FGFR; drug resistance; cancer; cancer treatment; anti-cancer drugs

\section{Introduction}

The development of resistance to pharmaceutical treatment is a common problem that affects a broad spectrum of diseases, in particular cancer. Despite current advances in medicine and the existence of many initially effective anti-cancer therapies, patients are often found to have cancer relapse, which is more malignant, invulnerable to treatment, and significantly correlates with poor prognosis [1]. Therefore, intensive research has been carried out for many years to develop new therapeutic strategies that may reduce the risk of recurrence of drug-resistant cancers [1,2]. A large range of mechanisms potentially involved in the emergence of chemoresistance exists, which severely hinders overcoming this problem. These mechanisms, often arising from DNA mutations and metabolism switching, include expression of efflux cell membrane transporters, drug inactivation, alteration in drug molecular targets, enhancing DNA repair machinery, epithelial-to-mesenchymal 
transition (EMT), or inhibition of apoptosis [1,3]. Another aspect is the diverse tumor microenvironment and heterogeneity of cancer cells, characterized by the formation of many subpopulations of cells with different drug sensitivity and the evolution of resistant clones [2]. It is supposed that this phenomenon may be of great importance in the recurrence of less sensitive or treatment-resistant cancers that may spread to other organs [1]. In recent years, particular attention has been paid to the involvement of growth factors and their receptors in processes leading to drug resistance, due to their biological functions and the frequent correlation of overproduction of these proteins with cancer progression [3,4]. EGF (epithelial growth factor), IGF (insulin-like growth factor), VEGF (vascular endothelial growth factor), and their receptors have been identified as key players in the response of cancer cells to cytotoxic drugs, but the exact mechanisms of this phenomenon have not been fully elucidated [5-8]. Recent studies suggest that fibroblast growth factors (FGFs) and their receptors (FGFRs) are also an important group of proteins in the development of drug resistance.

The FGF family includes 22 highly conserved proteins that interact with specific receptors (FGFR1-4) belonging to RTKs (receptor tyrosine kinases) [9]. The FGF binding forces the conformational changes of FGFRs, followed by receptor dimerization and transphosphorylation in the intracellular kinase domain [10]. This interaction is stabilized by heparan sulfate proteoglycans located on the cell surface, due to their high affinity to both FGFs and FGFRs [9]. Upon FGFR dimerization, its phosphorylated kinase domain recruits and activates adaptor proteins, including FRS2 $\alpha$ (fibroblast growth factor receptor substrate 2), which in turn interacts with GRB2 (growth factor receptor-bound 2) [11]. Furthermore, activated GRB2 recruits SOS1 (son of sevenless 1) to activate the RAS/MAPK (rat sarcoma virus protein/mitogen-activated protein kinases) pathway, which includes ERK1/2 (extracellular signal-regulated kinase 1/2) and p38, or GAB1 (GRB2-associated binding protein 1) to activate the PI3K/AKT/mTOR pathway (phosphoinositide 3-kinase/AKT/mammalian target of rapamycin) $[10,11]$. Independently of the interaction with FRS2 $\alpha$, activated FGFR kinase domain triggers activation of other signaling pathways, such as JAK/STATs (Janus kinases/signal transducers and activators of transcription) and PLC $\gamma /$ PKC (phospholipase $\mathrm{C} \gamma /$ protein kinase C) pathways [11]. Downstream FGF/FGFR signaling regulates pivotal cellular processes such as proliferation, differentiation, migration, and apoptosis, which govern embryogenesis, organs development and the maintenance of homeostasis in adult tissues $[9,11,12]$. Given the role of FGFs and FGFRs in cell and tissue development and function, they have been rapidly linked to tumorigenesis and chemoresistance occurring during anti-cancer therapy $[13,14]$. Here, the relationship between the action of FGF/FGFR and the occurrence of drug resistance in cancer cells is presented and their specific mechanisms of action are proposed to be considered as targets for cancer treatment.

\section{FGFs and Their Receptors in Cancer Progression}

In the late 1970s and early 1980s, FGFs and their specific receptors began to be associated with tumors $[15,16]$. Baird and co-workers showed that antibodies directed to FGF significantly decreased tumor size from transplantable chondrosarcoma [17]. At the same time, $F g f-3$ gene was identified as a proto-oncogene in MMTV (mouse mammary tumor virus)-induced tumor in mice [18]. In the following years, the number of correlations of FGFs and FGFRs with tumors increased [10]. Currently, ample evidence points to a role of unusual occurrence of FGFs and/or their receptors in the progression of cancer, including breast, lung, prostate, colorectal, brain, and other cancers, which is usually associated with poor patient prognosis $[10,13]$. However, there are reports showing that FGF2/FGFR2 protein level in glioma and breast cancer tissue does not differ from that in non-malignant parental cells, or is even lower $[19,20]$.

A number of dysfunctional aberrations, such as gene amplification, chromosomal translocations, or missense point mutations have been identified in FGFs and FGFRs genes in various cancers [12,21-24]. These anomalies often lead to overexpression of FGFs or their receptors, the formation of fusions of FGFRs with other proteins and/or the generation 
of a constitutively active kinase domain in FGFRs (Figure 1) [10]. This may result in imbalanced FGFRs-dependent cell signaling, which in turn facilitates uncontrolled cell proliferation, evasion of apoptosis, angiogenesis, and EMT (Figure 1) [10,11]. This may also cause genome instability, leading to further random mutations and the emergence of other mechanisms driving tumorigenesis [25]. However, it is still unclear whether the dysregulation of FGF/FGFR is directly responsible for carcinogenesis or whether the abnormalities, caused by genome instability, are site effects and only drive neoplastic progression. Nevertheless, FGFs and their receptors play an important role in cancer development and deregulated intracellular signaling may be largely responsible for the formation of malignant tumors, resistant to chemotherapy.

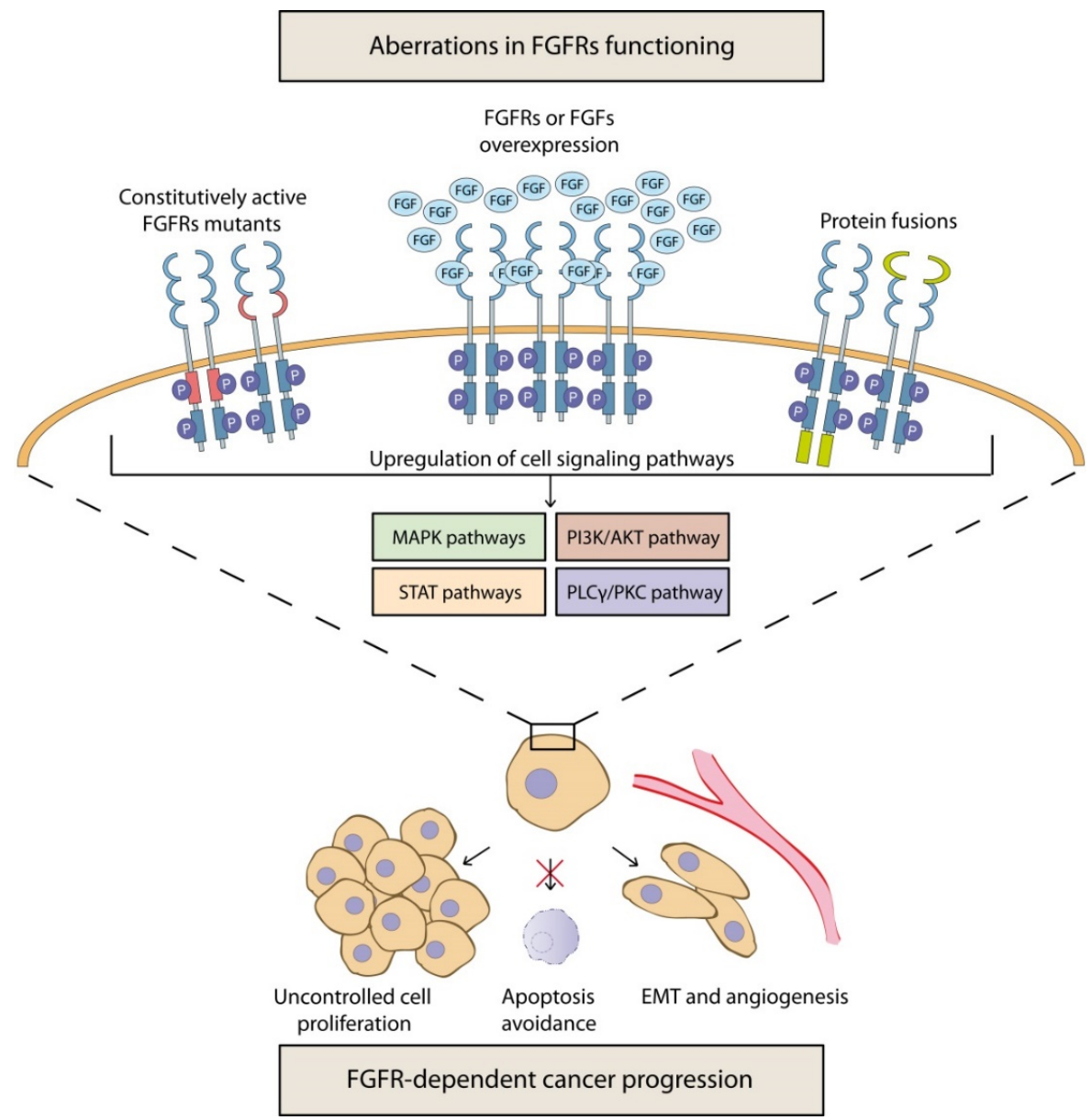

Figure 1. FGFRs-mediated mechanisms of cancer development and progression. Fibroblast growth factor receptors (FGFRs) and their natural ligands (FGFs) are involved in many biological processes, crucial for the proper operating of the cells and entire organism. However, many aberrations in FGFRs and/or FGFs genes may generate deregulations in the FGFRs/FGFs axis, which often upregulate downstream cell signaling and drive tumorigenesis. Activating mutations may lead to ligand-independent receptor dimerization and activation or creating the constitutively active kinase domains. The amplification of FGFRs or FGFs genes results in protein overexpression, which may also contribute to enhanced FGFRs-mediated cell signaling. Chromosomal translocations lead to the formation of fusion proteins that in some cases cause, similarly to activation mutations, receptor activation independently of FGFs presence. Regardless of the type of FGFRs dysfunction, the consequence is upregulated cell signaling that may drive cancer progression, through uncontrolled cell division, apoptosis avoidance, new blood vessel formation and/or EMT. 


\section{The Role of Cell Signaling Pathways in the Development of Anti-Cancer Drug Resistance}

The increasing number of cases correlating FGF and FGFR expression in cancer cells with treatment failure and poor patient prognosis highlights the important role of these proteins in the cellular response to anti-cancer drugs. FGFs and FGFRs have been associated with resistance to several cytotoxic agents, such as paclitaxel, cisplatin, etoposide, 5fluorouracil, doxorubicin, and others in various tumor types (Table 1) [26-36]. Most studies on the involvement of FGF proteins in the development of drug resistance involve FGF1 and FGF2, while there are a few reports on the role of other FGFs in this process, including FGF4, FGF5, FGF9, FGF10, FGF13, and FGF19 [37-44]. Overexpression of FGF receptors in cancer cells has also been observed with a concomitant reduction in response to protein kinase inhibitors (including RTKs) or endocrine therapy (Table 1) [39,45-50]. To investigate the involvement of FGF proteins and their receptors in the process of chemoresistance, particular attention has been paid to FGFR-dependent signaling pathways and their downstream targets, which can lead to deregulation of a number of biological processes, including apoptosis and metastasis.

Table 1. Examples of resistant cancer types associated with FGF/FGFR.

\begin{tabular}{|c|c|c|c|}
\hline Cancer Type & Drug & Involved Protein(s) & References \\
\hline \multirow{8}{*}{ Breast cancer } & Etoposide & \multirow{4}{*}{ FGF2 } & \multirow{2}{*}{ [30] } \\
\hline & 5-fluorouracil & & \\
\hline & Mifepristone, Telepristone & & [50] \\
\hline & Paclitaxel & & {$[31,33]$} \\
\hline & Tamoxifen & FGF1, FGFR2 & {$[48,51]$} \\
\hline & \multirow{2}{*}{ Trastuzumab } & FGFR4 & [49] \\
\hline & & \multirow[t]{2}{*}{ FGF4 } & \multirow[t]{2}{*}[43]{} \\
\hline & Lapatinib & & \\
\hline \multirow{2}{*}{ Colorectal cancer } & 5-fluorouracil & FGFR4 & [52] \\
\hline & Irinotecan & FGF2, FGF9 & [37] \\
\hline \multirow{2}{*}{ Liver cancer } & \multirow{2}{*}{ Sorafenib } & FGF19, FGFR4 & [39] \\
\hline & & FGF9 & [42] \\
\hline \multirow{3}{*}{ Head and neck cancer } & Paclitaxel & FGF2 & [31] \\
\hline & Cisplatin & FGF2, FGFR2 & [35] \\
\hline & Bevacizumab & FGF2, FGFR3 & [53] \\
\hline \multirow{3}{*}{ Lung cancer } & Gefitinib & FGFR1 & [54] \\
\hline & Cisplatin & FGF2 & [36] \\
\hline & Erlotinib & FGFR1 & [45] \\
\hline \multirow{2}{*}{ Bladder cancer } & Cisplatin & \multirow{2}{*}{ FGF2 } & [27] \\
\hline & Paclitaxel & & [31] \\
\hline \multirow{3}{*}{ Prostate cancer } & Doclitar & FGF2 & [31] \\
\hline & Doxorubicin & \multirow[t]{2}{*}{ FGF1, FGF2 } & \multirow[t]{2}{*}{ [29] } \\
\hline & 5-fluorouracil & & \\
\hline \multirow{3}{*}{ Blood cancer } & Cytarabine & \multirow{2}{*}{ FGF2, FGFR1 } & \multirow{2}{*}{ [55] } \\
\hline & Etoposide & & \\
\hline & Fludarabine & FGF2 & [26] \\
\hline
\end{tabular}


Table 1. Cont.

\begin{tabular}{cccc}
\hline Cancer Type & Drug & Involved Protein(s) & References \\
\hline \multirow{2}{*}{$\begin{array}{c}\text { Ovarian and } \\
\text { cervical cancer }\end{array}$} & Paclitaxel & FGF2 & {$[31]$} \\
\cline { 2 - 4 } & Etoposide & FGF1 & {$[56]$} \\
\cline { 2 - 4 } Brain cancer & Cisplatin & FGF13 & {$[38]$} \\
\cline { 2 - 4 } & Temozolomide & FGFR1 & {$[57]$} \\
\cline { 2 - 4 } Melanoma & Paclitaxel & FGF2 & {$[58]$} \\
\cline { 2 - 4 } & Cisplatin & FGF2 & {$[34]$} \\
\hline Bone cancer & Vemurafenib & FGF2 & {$[47]$} \\
\hline
\end{tabular}

Cancer cell signaling is a highly unpredictable "life-to-death" machinery due to the interference of multiple independent factors. Therefore drug-resistant tumors frequently exhibit deregulations in more than one signaling pathway, with growth factor-associated cascades often playing a significant role here [3,11]. A growing number of cases indicate that mutations in various signaling proteins, aberrant signal transduction, and abnormal cross-talks between different cascades are key problems in overcoming the after-treatment recurrence of more aggressive and resistant cancers.

\subsection{MAPK Cascade}

Mitogen-activated protein kinases (MAPKs) are an integral part of signaling pathways with high mitogenic and pro-survival potential and include three main families: ERK family as mitogen-responsive and JNK and p38 kinase families as stress-responsive [59]. The MAPK pathways, initiated by G proteins (RAS for ERK and RAC, RHO or RAP for JNK and p38), are three-tiered kinase cascades that act through phosphorylation of subsequent kinases (MAPKKK, MAPKK, and MAPK) (Figure 2) and regulate many biological processes, such as embryogenesis, cell differentiation, proliferation, and cell death [60]. All three MAPK families have been reported to control apoptosis in response to anticancer drugs [59]. However, the activity of the RAS/RAF/MEK/ERK pathway is most commonly correlated with FGF/FGFR-dependent drug resistance in many types of cancer $[37,47,53,61]$. ERK upregulation caused by increasing FGFR3 level in HNSCC (head and neck squamous cell carcinoma) cells led to an increase in FGF2 expression, which correlated with reduced sensitivity to bevacizumab (Figure 2) [53]. In colorectal cancer (CRC) cells, resistance to irinotecan, a topoisomerase I inhibitor, was dependent on FGF2 and FGF9 expression followed by MAPK pathway activation [37]. FGF9 seems to have a key role in irinotecan resistance as it correlates with other identified genes, such as Prkacb (cAMP-dependent protein kinase catalytic subunit beta) and Macom (MDS1 and EVI1 complex locus protein EVI1), and also with Ffg2 and Pla2g4c (cytosolic phospholipase

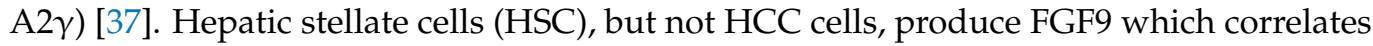
with poor patient survival [42]. However, the exogenous addition of FGF9 in HCC cells activated ERK and JNK, and led to a decrease in sorafenib sensitivity, which suggests the FGF-dependent HSC-HCC cross-talk in liver cancers [42]. The reactivation of ERK seems to be crucial for the resistance to BRAF inhibitors in melanoma cells with BRAF-V600E mutations, and one of the mediators is FGFR3 [47]. In BRAF/MEK inhibition-resistant cancer cells carrying BRAFV600E mutation, the dual MAPK inhibition drives the overexpression of FGF1 followed by the FGFR activation and the reactivation of ERK [62]. The addition of FGFR inhibitors re-sensitized cells to combination treatment with vemurafenib and cobimetinib, BRAF and MEK inhibitors, respectively [62]. Resistance to trametinib (MEKs inhibitor) treatment via FGFR1-dependent activation of ERKs and AKT was also observed 
in lung and pancreatic cancer cells with mutated KRAS [61]. Similarly, reactivation of ERKs by exogenous FGF4 in HER2-positive breast cancer led to the resistance to dual HER2 inhibition [43].

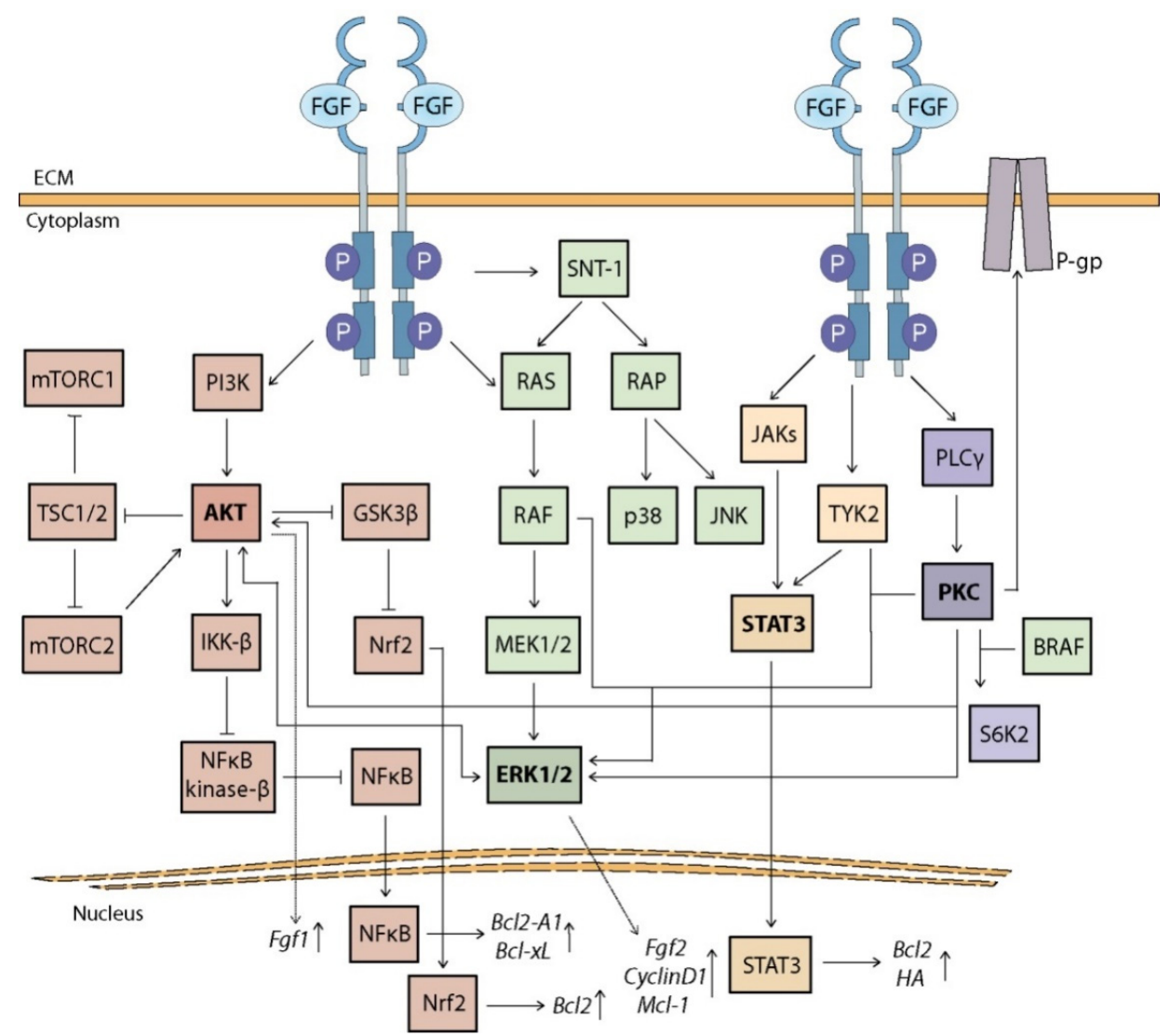

Figure 2. FGFR-dependent cell signaling in the development of drug resistance. Many drugs show reduced efficacy over time. Recent studies have linked this phenomenon to activation of FGFR and disruption of its downstream signaling including mutations of individual signaling proteins, impaired signal transduction and cross-talks between different cascades. The mode of action of $\mathrm{PI} 3 \mathrm{~K} / \mathrm{AKT}$ in the development of chemoresistance is mainly based on the upregulation of prosurvival genes such as $B c l 2-A 1$ or $B c l-x L$ by activation of IKK $\beta$ or inactivation of GSK3 $\beta$ and further nuclear translocation of NFKB or Nrf2, respectively. Another mechanism is inhibition of TSC1/2 affecting protein synthesis. Activation of ERK kinases in MAPK pathway appears to be crucial in the acquisition of drug resistance, as it leads to increased expression of proteins associated with cell cycle progression (e.g., cyclin D1) and apoptosis control (e.g., Mcl-1). Another signaling pathway STAT, in particular STAT3, can directly affect the tumor microenvironment through increased hyaluronan (HA) synthesis, as well as the regulation of apoptosis through Mcl-1 or Bcl-xL. Finally, the PLC $\gamma /$ PKC pathway is often complicit in other signaling cascades and is also able to directly activate multidrug resistant proteins such as P-gp.

Another concern is the development of resistance to tamoxifen, an antagonist of estrogen receptor (ER), commonly used in breast cancer therapy [1]. In vivo studies in ER-positive breast cancer (MCF-7 cells) showed that resistance to tamoxifen treatment is dependent on reactivation of ERK1/2 and p38 kinase [8]. Zhang and co-workers showed that overexpression of FGF1 promotes tumor growth in breast cancer treated with tamoxifen [48]. A similar effect was observed for FGF2 and FGF4 [63,64]. Administration of exogenous FGF1, but not EGF, reduced the inhibitory effect on ERK1/2 activation by MEK inhibitors and reduced the inhibition of tumor growth by the ER antagonist ICI 182780 in MCF-7 cells [65]. Other studies showed that amplification of FGFR1, FGFR2, or FGFR3 in ER-positive human breast cancers correlates with concomitant resistance to 
estrogen-related therapy [65-69]. The mechanism is probably based on prolonged ERK1/2 activation after FGF/FGFR stimulation [65,66]. It has been suggested that it depends on RAP1 (RAS-proximate-1 or Ras-related protein 1) and SNT-1 (Suc1-associated neurotrophic factor-induced tyrosine-phosphorylated target)/FRS2 rather on RAS or RAF-1 proteins (Figure 2) [65]. Stimulation with FGFs causes SNT-1/FRS2 phosphorylation and its binding to FGFRs via the phosphotyrosine-binding domain, which consequently leads to activation of downstream signaling pathways through its interaction with adaptor proteins GRB2, GAB1 and SOS1 [65]. Inhibition of the interaction between SNT-1/FRS2 and FGFRs decreases MAPK, PI3K, and mTOR activity, leading to a reduction in anti-estrogen resistance induced by FGF1 stimulation [69]. Furthermore, FGFR1 signaling activation decreased progesterone receptor expression [69]. FGF2/FGFR-dependent ERK activation induced cyclin D1 expression, which activates key mediators of cell cycle progression, cyclin dependent kinases 4 and 6 (CDK4, CDK6), in ER-positive breast cancer (Figure 2) [64]. Turner and co-workers have shown that stimulation with FGF2 led to the development of resistance to tamoxifen in breast cancer cells with elevated expression of FGFR1 [66]. It has been suggested that FGF2/FGFR1 signaling is essential for overcoming tamoxifen action, and this process has been associated with high activity of MAPK and AKT cascades as well as increased level of cyclin D1 [66].

\subsection{PI3K/AKT Cascade}

Protein kinase B (PKB), also known as AKT, is a major downstream effector of PI3K and one of the main perpetrators associated with the resistance to various anti-cancer agents, including cisplatin, paclitaxel, etoposide, RTKs inhibitors, as well as radiation [70-74]. Activated by PI3K and mTORC2 (mammalian target of rapamycin complex 2), AKT directly or indirectly exerts control over the activity of various intracellular processes, including apoptosis, through inactivation of proapoptotic BAD (Bcl-2 antagonist of cell death), BIM (Bcl-2-like protein 11), pro-caspase 9, and/or FOXO (forkhead box protein O1) proteins or phosphorylation of MDM2 (mouse double minute 2 homolog) followed by increased p53 (cellular tumor antigen p53) degradation; protein synthesis, by inhibition of TSC1/2 (tuberous sclerosis complex 1/2, mTOR inhibitors) and subsequent activation of mTORC1 (mammalian target of rapamycin compex 1); and cell cycle regulation through inhibition of the cyclin-dependent kinase inhibitors, p21 and p27, or glycogen synthase kinase $3 \beta$ (GSK3 $\beta$ ), which prevents cyclin D1 degradation [75]. AKT can also regulate angiogenesis and cell migration, which in turn can lead to EMT in cancer cells [76]. The PI3K/AKT pathway has been indicated as a major player in FGF/FGFR-dependent tumor progression with a significant role in the regulation of apoptosis and the development of chemoresistance $[57,67,77,78]$. The interaction of FGF2 and FGFR1, through activation of the PI3K/AKT pathway, mediates cell survival, proliferation, motility, and consequently resistance to cytarabine and paclitaxel treatment [55,79].

The use of anti-FGFR1 antibody reduces AKT phosphorylation, inhibits tumor growth and restores drug sensitivity both in vitro and in vivo [55]. FGF/FGFR activity plays also an important role in acquired resistance to EGFR inhibitors [80-83]. Overexpression of FGFR1 in resistant to gefitinib (EGFR inhibitor) NSCLC (non-small-cell lung cancer) cells led to increased activation of AKT and mTOR, whereas FGFR1 inhibition decreased phosphorylation of both kinases and re-sensitized cells to gefitinib $[54,83]$. The investigation into the role of the PI3K/AKT pathway in FGF2-dependent resistance to etoposide, 5fluorouracil, camptothecin, and the $\mathrm{C} 2$ ceramide analogue in breast cancer cell lines (MCF-7, T47-D, and BT-20) revealed subsequent AKT-dependent stimulation and translocation of nuclear factor- $\mathrm{KB}(\mathrm{NF} \kappa \mathrm{B})$ to the nucleus via activation of IKK- $\beta$ (inhibitors of NFKB kinase$\beta$ ), but not on the MAPK pathway [30]. Further studies have revealed that FGF2/PI3Kdependent translocation of $\mathrm{NF} \kappa \mathrm{B}$ mediates transcriptional upregulation of pro-survival $B c l 2-A 1$ (Bcl-2-related protein A1) and Bcl-xL (Bcl-2-like protein 1) genes (Figure 2) [84]. Gao and co-workers demonstrated that FGF19/FGFR4 signaling in hepatocellular carcinoma (HCC) cells is one of the main resistance mechanisms to sorafenib, a multikinase inhibitor inducing the ROS (reactive oxygen species)-associated apoptosis [39]. Further research 
revealed that overexpression of FGF19 induced by endoplasmic reticulum stress in HCC cells leads to increased resistance to apoptosis through the inactivation of GSK3 $\beta$ and subsequent nuclear translocation of Nrf2 (nuclear factor E2-related factor 2) (Figure 2) [85]. FGFR-mediated activation of the PI3K/AKT pathway is also observed in cancer cells during BRAF (serine/threonine-protein kinase B-raf) or MEK (mitogen-activated protein kinase kinase) inhibitors treatment $[62,86,87]$. In neural stem cells, transactivation of FGFR1 by Notch2 (neurogenic locus notch homolog protein 2) led to GSK3 inhibition via $\mathrm{AKT}$, but independently from mTOR activation, resulting in a reduced response to etoposide [58]. Knock-down of FGF2, but not EGF or insulin, re-sensitized these cells to treatment. Interestingly, inhibition of the mTOR pathway, but not the PI3K pathway, in triple-negative breast cancer cells led to increased FGF1 and Notch1 expression, enhanced FGFR1 activation and the formation of a resistant cancer stem cell-like population [88].

Recently, autocrine FGFR activation has been correlated with HES1 (hairy and enhancer of split-1) expression and AKT-dependent cell proliferation in endometrial cancers insensitive to Notch inhibition [89]. HES1 has been also identified as a potential driver of anti-cancer drug resistance, in addition to upregulation of cancer cell proliferation and migration [90]. The development of resistance to the BRAF inhibitor (vemurafenib) in melanoma cancer cells was correlated with the induction of transcription and secretion of FGF1 through enhanced activity of PI3K/AKT pathway and FRA1 (Fos-related antigen 1) (Figure 2) [87]. Expression of FGF2 by endothelial cells promoted prostate cancer cells proliferation and led to the acquisition of docetaxel resistance via activation of the AKT/mTOR pathway and upregulation of the erythroblast transformation specific related gene [91]. In ovarian cancer, the FGFR/PI3K/AKT pathway has been implicated in the development of cisplatin resistance induced by the GLT8D (glycosylotransferase 8 domain containing2) protein through the interaction with FGFR1 and the subsequent signaling activation [92].

Additionally, the FGF7 /FGFR2 axis has been identified as driving tamoxifen resistance in breast cancer cells (T47-D, MCF-7). It has been shown that FGFR2 activation counteracted the effect of tamoxifen on ER stabilization and that the acquisition of resistance to the aforementioned drug was promoted by the PI3K/AKT cascade and not by MAPKs, further targeting ER-Ser167 and Bcl-2 expression [51]. They showed that FGFR2 signaling promoted ER ubiquitination and suggested that the ER degradation/turnover is the main mechanism responsible for the suppressed cellular response to tamoxifen [51]. This observation is in agreement with previous work confirming that CUEDC2 (a ubiquitin-binding motif-containing protein which regulates ER degradation) is the molecule that leads to resistance to tamoxifen-based therapy [93].

\subsection{STAT Cascade}

Another important group of proteins activated by extracellular signals transmitted by RTKs and involved in cancer progression and survival are signal transducers and activators of transcription (STATs), in particular STAT3 and STAT5 [94]. Upon activation by receptorbound JAK1-3 (Janus kinases) and TYK2 (tyrosine kinase 2), phosphorylated STATs form homo- or heterodimers and translocate to the nucleus, where they act as transcription factors [94,95]. STATs directly target genes that regulate cell cycle, such as cyclin D1, p21, $c-m y c$, and apoptosis, such as Bcl- $x \mathrm{~L}$ and $\mathrm{Mcl}-1$ (myeloid cell leukemia sequence 1), and thus may also affect cellular response to anti-cancer drugs [95]. FGF/FGFR-dependent STAT3 activity has been correlated with resistance to doxorubicin, 5-fluorouracil, cisplatin, paclitaxel, and MEK/BRAF inhibitors in several cancers [52,96]. Activation of FGFR1 induces hyaluronan (HA) synthesis via STAT3 pathway and causes accumulation of HA in extracellular matrix (ECM) of breast cancer cells (Figure 2) [96]. Inhibition of HA synthesis and / or accumulation by STAT3 inhibition reduces cell migration and proliferation, and partially reverses resistance to doxorubicin [96]. Overexpression of FGFR3 decreases apoptosis in multiple myeloma cells, with concomitant increase in STAT3 phosphorylation and Bcl-xL expression (Figure 2) [97]. Another study demonstrated that resistance to 
5-fluorouracil and oxaliplatin in CRC cells was associated with the upregulation of FGFR4 and subsequent STAT3 activity [52]. Additionally in CRC, the FGFR2/JAK/STAT3 pathway promotes the expression of programmed cell death ligand 1 (PD-L1), a transmembrane protein associated with reduced T-cell proliferation [98].

Recently, studies in EGFR-positive cancer cells have shown that sustained activation of STAT3, due to enhancement of its binding to FGFR1, plays a key role in the acquisition of resistance to EGFR inhibitors [99]. Moreover, STAT3 activation was independent of gp130/JAK activity or HER2/EGFR heterodimer formation and administration of PD173074 led to suppression of STAT3 activation and inhibition of cancer cell proliferation [99]. Interestingly, in the osteosarcoma U2OS cells, FGF2-dependent drug resistance was determined by activation of JAK1, JAK2, and TYK2, but not STATs activation [100].

\subsection{PLC $\gamma /$ PKC Cascade}

Finally, phospholipase $\mathrm{C} \gamma$ (PLC $\gamma)$ is also a very important signaling mediator involved in many biological processes, acting by cleavage of PIP2 (phosphatidylinosi-tol4,5-bisphosphate) into IP3 (inositol-1,4,5-triphosphate) and DAG (diacyloglycerol), and regulating $\mathrm{Ca}^{2+}$ channels and PKC activity [101]. Aberrations in the PLC $\gamma /$ PKC pathway also contribute to the development and progression of many types of cancers, but their role in the drug sensitivity is not fully elucidated [101]. PLC $\gamma$ acts primarily by PKC activation as a regulator and/or alternative activator of other pro-survival proteins, such as AKT or RAS (Figure 2) $[5,67,101]$. Activated PKC can also phosphorylate multidrug resistance proteins, such as P-gp (P-glycoprotein 1, also known as MDR1 or ABCB1) (Figure 2) [31]. It has been observed that increased expression of FGF2, but not FGF1, in tumors with reduced sensitivity to paclitaxel also correlates with increased level of Pgp [31]. In FGF/FGFR-dependent mechanisms of drug resistance involving other signaling pathways, co-involvement of the PLC $\gamma /$ PKC cascade has been observed, indicating an important role for PLC $\gamma$ in the development of molecular cross-talks necessary for cell survival [53,67,102,103].

\section{Signals from the Tumor Microenvironment}

It is well established that the complex tumor microenvironment can play an important role in cancer progression, metastasis, as well as in gaining the resistance to treatment. Its components including ECM, immune cells, blood vessels, cytokines and growth factors, and non-epithelial cells, especially cancer-associated fibroblast (CAFs), provide additional pro-survival stimuli to adapt to treatment and evade therapies. Activated fibroblasts acquire an invasive phenotype and promote tumor growth and proliferation via paracrine and autocrine pathways, further fueled by the immune response [104,105].

Members of FGF family (including FGF1, FGF2, FGF4, FGF5, FGF6, FGF7, and FGF9) were reported to be secreted by CAFs [51,106-108] and FGFR2 was shown to be a key mediator of tumor niche-derived signals that are responsible for the acquisition of tamoxifen resistance [51]. In addition, FGF2 secreted by CAFs was found to contribute to lung cancer cells growth through overexpression of Tgfb, Mmp7, Fgf2, Fgf9, enhanced collagen synthesis, and increased expression of inflammatory cytokines such as Csf1, Cxcl12, and Ccl2 [109]. Furthermore, FGF1 promotes tumor-niche fibroblasts to express and secrete HGF (hepatocyte growth factor), a mediator of angiogenesis and cell motility, and an important tumor-resistant factor in melanomas [87].

Another study showed that HGF secreted by CAFs induced FGF2 secretion by HNSCC in order to drive glycolysis for extensive use of glucose for their growth and survival [110]. Additionally in pancreatic adenocarcinoma, CAFs secrete FGF2, which enhances cancer survival by increasing CXCL8 level [111]. In HER-positive breast cancer, the secretion of FGF5 by CAFs leads to FGFR2 activation in cancer cells and acquisition of resistance to trastuzumab and lapatinib (EGFR/HER2 inhibitors) through FGFR2/c-Src-mediated HER2 transactivation [112]. Furthermore, FGF2 secreted by CAFs stimulated cell migration and 
invasiveness in a breast cancer cell line (MDA-MB-231), which could be inhibited by an FGF2-neutralizing antibody [113].

\section{Cross-Talks between FGF/FGFR Signaling Pathways in Cancer}

Due to the frequent involvement of more than one pathway and the formation of molecular cross-talks between them, it is difficult to pinpoint the main mechanism responsible for the impaired cellular response to anti-cancer treatment. For instance, RAS/MAPK and PI3K/AKT pathways may alternately activate when one pathway is inhibited, thereby preventing apoptosis in cancer cells [114]. Clinical studies indicate that parallel inhibition of the PI3K/AKT and RAS/MAPK pathways can significantly improve treatment efficacy, especially in advanced cancers with genetic alterations in these pathways [115]. Interestingly, also in doxorubicin-treated non-cancerous NIH3T3 cells, the PI3K/AKT and p38 MAPK pathways were transiently activated and their chemical inhibition accelerated and enhanced drug-induced apoptosis, whereas the ERK and JNK pathways were continuously active and their inhibition repressed the apoptotic function of doxorubicin [116]. Moreover, AKT activity has been shown to negatively affect long-term ERK phosphorylation followed by PARP (poly (ADP-ribose) polymerase) cleavage and caspase activation during doxorubicin-induced cell death [116]. In KRAS mutant cancer cells, only inhibition of both the PI3K/AKT and MEK pathways resulted in complete inactivation of mTOR and increased cell death (Figure 2) [117]. Increased phosphorylation of both AKT and ERKs was commonly observed in cancer cells treated with RAS/MAPK pathway inhibitors, suggesting the importance of the PI3K/AKT pathway in reactivating ERKs and reducing the cytostatic effect of the inhibitors (Figure 2) [61,62,118]. In lung and pancreatic cancer cells with mutated KRAS, treatment with trametinib, a MEK inhibitor which acts downstream of KRAS to suppress MAPK cascade, led to a compensatory response through activation of FGFR1 and subsequent phosphorylation of FRS2, thus resulting in alternative signal transduction and generating adaptive drug resistance [61]. Inhibition of FGFR1 in combination with trametinib treatment induced cell death in KRAS-mutant cancer cells [61]. Another study showed that in HNSCC cells, co-inhibition of MEK and FGFR3 activity reduced AKT and ERKs phosphorylation, which in turn led to increased DNA fragmentation, caspase 3 cleavage, and reduced tumor growth in vivo [118].

One of the multi-functional mediators of linking different signaling pathways is the aforementioned PLC $\gamma /$ PKC pathway. PLC $\gamma$ downstream signaling has been shown to activate MAPK and PI3K pathways in the development of resistance to estrogen-related therapy (Figure 2) [67]. Additionally, increased FGF2 expression in bevacizumab-resistant HNSCC cells, accompanied with upregulation of PLC $\gamma$, ERKs, and AKT, correlated with the reduced sensitivity to the bevacizumab treatment [53]. Other studies indicate an important role for the interaction of MAPKs and S6K2 (ribosomal p70 S6 kinase 2) in FGFsdependent cancer cells proliferation and survival $[102,119]$. As a consequence of FGF2 stimulation, PKC $\varepsilon$ complex formation with BRAF and S6K2, but not with S6K1 and RAF-1, induced drug resistance in SCLC (small cell lung cancer) cells, HEK293 and U2OS cells (Figure 2) [100,102]. FGF2 was also found to mediate the interaction of TYK2 with PKC $\varepsilon$ and BRAF, leading to full phosphorylation of ERK1/2, MCL-1 activation and inhibition of apoptosis (Figure 2) [100]. Furthermore, another phospholipase, PLA2G4C (cytosolic phospholipase A2 $\gamma$ ), has been linked together with FGF9 and the MAPK pathway to irinotecan resistance in CRC cells [37].

\section{Dysregulation of Apoptosis in Cancer by FGFs/FGFRs System}

One of the most essential processes for the functioning of cells and the whole organism is apoptosis, a programmed cell death, controlled by two main pathways: extrinsic (death-receptor pathway) and intrinsic (mitochondrial-mediated pathway) [120]. Increased survival of cancer cells by avoiding apoptosis is one of the most potent mechanisms of tumor progression and drug resistance [2]. A majority of anti-cancer drugs act by activating apoptosis mediated by cell cycle inhibition, DNA damage, immune surveillance, and other 
cellular stresses [2]. Therefore, alteration of pathways involved in cell death and imbalance between activators (such as BAD or BAX) and inhibitors (such as Bcl-2 or Bcl-xL) of apoptosis often leads to reduced drug sensitivity and the development of chemoresistance in tumors $[2,120]$.

The action of FGFs and their receptors is also involved in the regulation of apoptosis, mainly through the activation of downstream signaling, such as PI3K/AKT, MAPKs, or STATs $[10,97,121]$. Several studies have shown that FGF2 regulates apoptosis through upregulation of Bcl-2, Bcl-xL, Mcl-1, and XIAP (X-linked inhibitor of apoptosis protein) $[78,84,100,102,121,122]$. In addition, Sun and co-workers have reported that FGF2 increases the expression of survivin, an anti-apoptotic protein that acts by inhibiting caspase 3 and 7 and linked this to the PI3K/AKT pathway in HCCs [78]. FGF2 has also been found to increase mitochondrial localization of $\mathrm{Bcl} 2-\mathrm{A} 1$ and $\mathrm{Bcl}-\mathrm{xL}$ proteins via the PI3K/NFKB pathway [84]. Other work has indicated that increased levels of Bcl-xL and XIAP correlate with FGF2dependent upregulation of PKC $\varepsilon$ [102]. FGF2 was also shown to protect SCLC cells from etoposide-induced apoptosis through upregulation of $\mathrm{Bcl}-\mathrm{xL}$ and $\mathrm{Bcl}-2$ at the translational level via the MEK pathway (Figure 3) [121]. On the other hand, the action of FGF1 or FGF2 was associated with inhibition of pro-apoptotic proteins, indicating a dual mode of action of FGFs in inhibiting apoptosis $[121,123,124]$. FGF2 has been shown to prevent cisplatin-induced activation of p53 by increasing MDM2 expression and block etoposide-triggered induction of BAD (Figure 3) [123]. FGF2 can also lead to MDM2 stabilization and enhanced p53 degradation by increasing the transcription of Enigma protein, which directly interacts with MDM2, forms a ternary complex with p53, and prevents MDM2 self-ubiquitination (Figure 3) [125]. It has been noted that only intracellular and not extracellular FGF1 affects p53-dependent apoptosis by increasing MDM2 expression [124]. However, it is known that exogenous FGF1 and FGF2 can translocate into the cytoplasm and cell nucleus independently of FGFRs activation, which is correlated with increased cell survival under stress conditions [126,127].

Inside the cell, FGF1 and FGF2 interact with many intracellular proteins, including p53, HSP90 (heat shock protein 90), CK2 (casein kinase 2), and others involved in the regulation of cell signaling, cell cycle, and apoptosis, which may contribute to the acquisition of drug resistance [128]. In PC12 cells, nuclear localization of FGF1 determines its anti-apoptotic effect, whereas in ovarian cancer cells FGF1 affects mitochondrial localization of p53 and reduces etoposide- and cisplatin-induced apoptosis (Figure 3) [56,129]. Of note, the nuclear FGF2 was associated with doxorubicin resistance in triple negative breast cancers with high level of DNA-dependent protein kinase, which is responsible for repairing double-stranded breaks in DNA [130]. Knockdown of FGF2 restored sensitivity to doxorubicin treatment. Furthermore, also nuclear localization of the FGF receptor has been associated with cancer progression and invasiveness [131-133]. In NSCLC cells, the importance of EGFR, another RTK, localized in the nucleus has been confirmed in the development of resistance to cetuximab, suggesting that FGFRs nucleocytoplasmic transport may also contribute to the development of drug resistance [134]. Treatment of patients with ER+/FGFR1-amplified breast cancers with letrozole, an aromatase inhibitor, increased the expression of FGFR1 and FGFs, as well as the nuclear localization of FGFR1 and ER $\alpha$ [135]. Estrogen deprivation led to an interaction between FGFR1 and ER $\alpha$ in the nucleus of cancer cells and subsequent regulation of ER-dependent genes transcription. This FGFR1:ER $\alpha$ interplay was abolished by the administration in the presence of TKIs (tyrosine kinase inhibitors) inhibitors or a kinase-dead FGFR1 mutant [135]. Another study has shown that doxorubicin treatment led to the formation of resistant cancer cell clones characterized by upregulated FGFR4 and $\mathrm{Bcl}-x \mathrm{~L}$ genes expression [136]. FGFR4 knockdown in these cells reduced ERK1/2 activity and Bcl-xL expression and resulted in re-sensitization of the cells to the drug [136]. Moreover, siRNA-mediated silencing of FGFR4 in CRC cells decreased the expression of Bcl-2 and c-FLIP (FLICE-like inhibitory protein), an inhibitor of caspase 8, while reducing STAT3 activity, which in turn induced caspase-dependent apoptosis (Figure 3) [52]. 


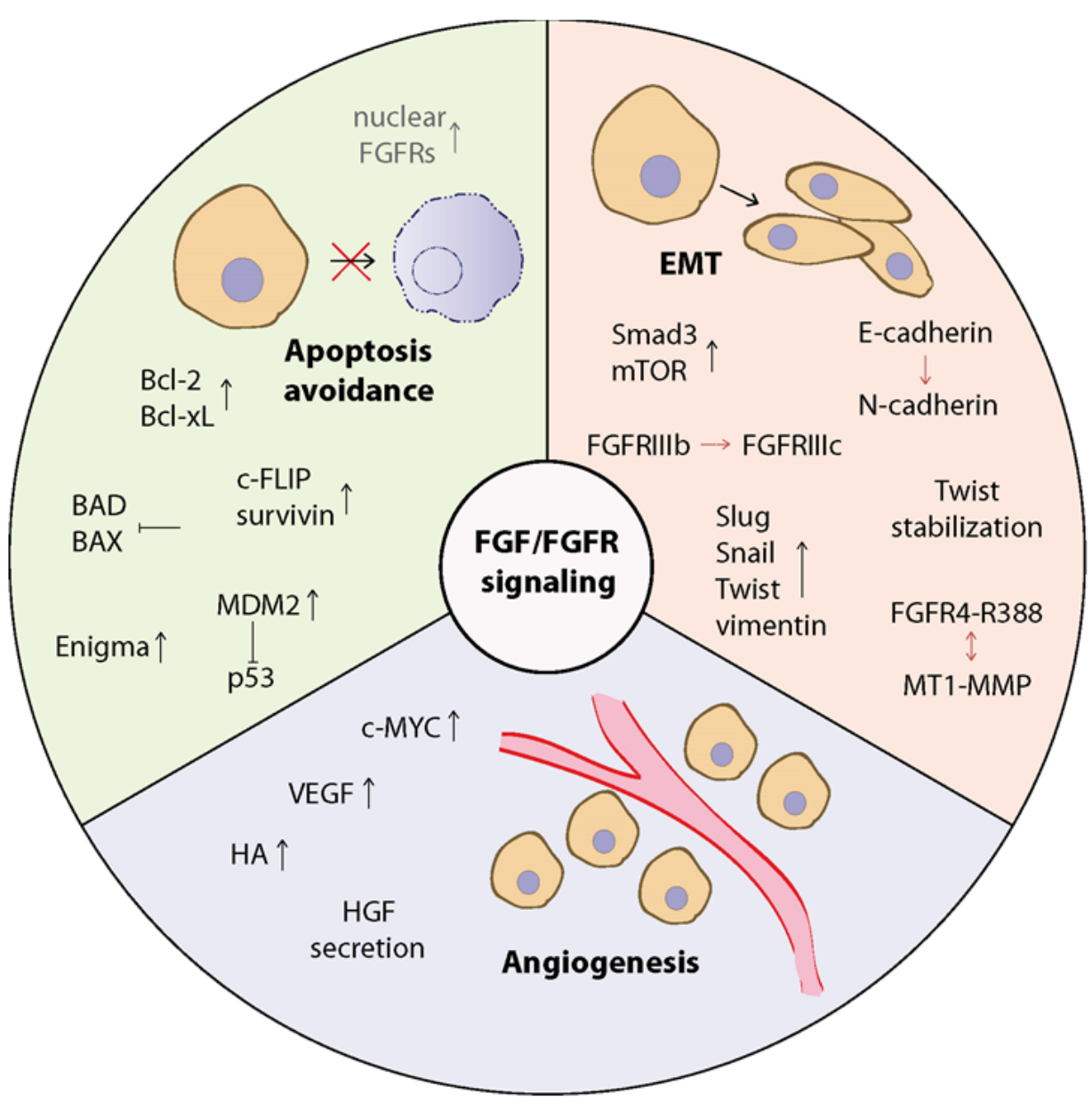

Figure 3. Involvement of FGF/FGFRs in cellular processes during the development of drug resistance. The active FGF/FGFR complex leads to avoidance of apoptosis through increased expression of apoptosis inhibitors (Bcl-2, Bcl-xL), inhibition of its activators (BAD, BAX) or activation and stabilization of MDM2, with consequent increased ubiquitination and degradation of p53. Additionally, p53 degradation can be enhanced by the formation of a ternary complex of p53, MDM2, and Enigma protein. Another mechanism of action is indirect inhibition of caspase $3 / 7$ and caspase 8 by increasing the expression of survivin or c-FLIP, respectively. It is also likely that increased nuclear localization of FGFRs may be associated with enhanced survival of cancer cells and development of drug resistance. FGF/FGFR (especially involving FGF2) also promotes angiogenesis through increased expression of VEGF, HA, and c-MYC, and enhanced secretion of HGF. EMT, in turn, is a consequence of activation of the MAPK signaling pathway leading to stabilization of Twist, switching of FGFR isoforms from IIIb to IIIc, switching of cadherins (from E-cadherin to N-cadherin), upregulation of mesenchymal markers (such as Twist and vimentin) and transcription factors (Slug and Snail), and activation of downstream signaling proteins (such as Smad3 and mTOR). Furthermore, the FGFR4-R388 mutant can interact with matrix metalloproteinases (e.g., MT1-MMP), proteins involved in tumor invasion.

\section{Role of FGFs/FGFRs Axis during Cancer-Associated Angiogenesis}

Angiogenesis, the formation of new blood vessels from existing vasculature, is an essential process in mammalian tissues, e.g., during embryogenesis or wound healing [137]. However, this process is also involved in the development of many pathological conditions including carcinogenesis, as it supplies tumors with nutrients, oxygen, and cytokines, and promotes neovascularization, growth, invasion, and metastasis of tumors [138-140]. Several growth factors are involved in the regulation of angiogenesis, both physiological and pathological, e.g., VEGF, PD-ECGF (platelet-derived endothelial cell growth factor), FGF2, which act as major angiogenic agents by stimulating endothelial cells growth and motility $[137,141]$. 
The FGF/FGFR signaling pathway is often disrupted during malignant tumor progression and there are several examples of its impact on tumor-associated angiogenesis $[138,140,142-145]$. Huang and co-workers showed that in addition to the proliferative effect on hepatoma cells, FGFR1 ectopic expression also upregulates VEGF expression, which in turn enhances angiogenesis necessary for later stages of cancer progression (Figure 3) [142]. Previous studies have shown that both VEGF and FGF2 act synergistically in tumor-driving angiogenesis [146,147]. On the other hand, in VEGFR-positive tumors, expression of FGF2 and FGF receptors was correlated with resistance to anti-VEGF therapy [148]. Another group reported that co-treatment of a T lymphoma cell line with HA and doxorubicin stimulated angiogenesis and this effect was FGF2-dependent rather than VEGF-dependent [149]. This revealed that the mechanism of negative response to doxorubicin is not only due to drug efflux, but also to angiogenesis [149]. Schönau and co-workers evaluated the effect of 5-fluorouracil-resistant colon carcinoma cells on endothelial cells growth [144]. The stimulatory effect of FGF2 released from cancer cells was higher in macrovascular endothelial cells than in microvascular cells [144]. Interestingly, the level of chemoresistance of cancer cells did not differentially affect growth of endothelial cells in vitro [144]. An increase in FGF2 and FGFR3 expression was also found in HNSCC cells resistant to bevacizumab, a monoclonal antibody targeting VEGF used as an antiangiogenic drug [53]. Simultaneous inhibition of VEGFR2 and FGFs blocked angiogenesis and tumor growth in pancreatic cancer resistant to anti-VEGFR treatment [150]. Furthermore, elevated levels of FGFR1 and FGFR3 associated with tumor progression and drug resistance, also correlated with expression of c-MYC, another protein responsible for tumor angiogenesis (Figure 3) [151-153]. Inhibition of FGFR3 in a urothelial cancer cell line or FGFR1 in a lung cancer cell line resulted in decreased c-MYC protein level $[153,154]$.

\section{Contribution of FGFs/FGFRs to EMT}

EMT results in the transformation of epithelial cells into cells with a mesenchymal phenotype [155]. In this process, epithelial cells lose cell polarity, cell-cell adhesion, and acquire the ability to migrate. EMT is involved in embryonic development, but also plays an important role in cancer pathogenesis, as cells become able to move to distant regions, leading to tumor invasion and metastasis $[155,156]$. Cells that have undergone EMT have lower expression levels of epithelial markers, such as E-cadherin, a cell adhesion molecule (CAM), while they exhibit higher expression of mesenchymal markers, including vimentin and fibronectin, as a result of upregulation of transcription factors from the zinc finger family, e.g., Twist, Slug, Snail, E12/E47 (E2A-encoded transcription factors), EF1/ZEB1 (elongation factor 1/zinc finger E-box-binding homeobox 1), and SIP1/ZEB2 (Smad interacting protein 1/zinc finger E-box-binding homeobox 2) $[157,158]$. Furthermore, during EMT, a decrease in E-cadherin level is accompanied by increased level of $\mathrm{N}$-cadherin, another CAM commonly expressed by mesenchymal cells, and this process is known as cadherin switching $[158,159]$. Most EMT processes are regulated by extracellular matrix components, cytokines, and growth factors, among which FGFs affect various functions by binding to FGF receptors [160-162]. One of the main inducers of EMT in many types of cancer is FGF2, which activates EMT through the MEK/ERK signaling pathway (Figure 3) [157]. In lung cancer cell lines (H1581 and DMS114), FGF2-dependent activation of the FGFR1/ERKs pathway led to upregulation of SOX2 (Sry-related HMG box 2), which in turn promoted EMT and cell migration [162]. Moreover, it has been suggested that high expression of both FGFR1 and SOX2 is associated with shorter survival of lung cancer patients [162]. However, SOX2 may be also regulated by the PI3K/AKT pathway, which is related with drug resistance in lymphoma [163]. Importantly, activation of epithelial FGFR1/2 by paracrine FGFs promotes tumor progression and induces EMT in vivo, which is associated with a switch of FGFR isoforms from IIIb to IIIc (Figure 3) [164-168]. In metastatic cancer cells, increased level of FGFR1c was triggered by transcription factor FOXC1, one of the predictors of EMT (Figure 3) [169]. Transformation of FGFR2b to FGFR2c also inhibited E-cadherin expression but increased vimentin expression (Figure 3) [168]. Furthermore, N- 
cadherin-induced tumor invasiveness was increased by FGF2, through stabilization of the FGF2-FGFR1 complex and sustained activation of the MAPK pathway [158]. Interestingly, the expression of FGFR2b in PC-3 cells caused the decrease in level of EMT markers [170]. EMT has been also found to contribute to the chemoresistance of cancer cells [171,172].

There are several examples demonstrating that upregulation of EMT markers can affect the drug sensitivity of cancer cells, e.g., in prostate cancer patients to docetaxel treatment or in NSCLC patients to cisplatin-based chemotherapy $[81,157,170]$. In lung and breast cancer cell lines resistant to ErbB inhibitors, the increased expression of FGFR1 and/or FGF2 accompanied EMT [81-83,173-175]. Another study showed that TGF $\beta$ (transforming growth factor $\beta$ ) and FGF2 efficiently induced EMT in human lung adenocarcinoma cell lines: in PC-9 cells via the Smad3 pathway, and in HCC-827 cells through Smad3, MEK/ERK, and mTOR pathways resulting in reduced sensitivity to gefitinib in both cell lines and to cisplatin only in HCC-827 cells (Figure 3) [81]. Inhibition of FGF2 or FGFR1 in a pemetrexed-resistant lung adenocarcinoma cell line resulted in downregulation of vimentin and Slug level, reversed EMT cell morphology, and partially restored sensitivity to pemetrexed [176]. Prifenidone and nintedanib reversed EMT-related chemoresistance induced by TGF $\beta$ and FGF2 in human lung adenocarcinoma cells [157]. Breast cancer cells resistant to lapatinib with a post-treatment mesenchymal phenotype showed increased level of FGFR1IIIc and FGF2 [177]. Interestingly, FGFR1 expression was induced by the EMT transcription factor Twist, while the following FGFR1-induced MAPK pathway stabilized Twist, and thus maintained the drug resistance (Figure 3) [177]. In afatinib-resistant lung cancer cell line, among EMT-related markers, only knockdown of Twist resulted in a complete downregulation of FGFR1, with concomitant inhibition of AKT and ERKs phosphorylation, which re-sensitized cells to afatinib [174]. Furthermore, FGFR1 was shown to contribute to acquired resistance to mesenchymal-epithelial transition by cabozantinib in prostate cancer PC-3 cells and that this process is regulated by YAP/TBX5 [178].

Studies in patients with primary breast cancer have shown that there is a correlation between the presence of FGFR4 polymorphism (FGFR4-Gly388Arg) and tumor aggressiveness and poor response to adjuvant CMF chemotherapy (cyclophosphamide/methotrexate/5fluorouracil) but not to endocrine therapy or NCT (neoadjuvant chemotherapy consisting of doxorubicin, cyclophosphamide, docetaxel, and pemetrexed) [179-181]. In patients with resected colon cancer (CC) or gastric cancer (GC), the R388 allele was associated with worse overall survival than the G388 allele, especially when fluorouracil/leucovorin or no adjuvant chemotherapy (in CC) or oxaliplatin (in GC) was used [182,183]. In contrast, HNC (head and neck cancer) and ovarian cancer patients carrying the FGFR4-R388 mutation exhibited increased sensitivity to cisplatin treatment, prolonged progression-free and overall survival $[184,185]$. This diversity is not fully understood, but the R388 allele correlates with increased cell motility and metastasis in many cancers [181-183,186,187]. In CC patients the presence of the R388 allele correlated with changes in EMT markers (increased vimentin and Twist, decreased E-cadherin), with concomitant upregulation of AKT, ERKs, and STAT3, compared with patients carrying the G388 allele (Figure 3) [182]. Similarly in NSCLC, FGFR4-R388 led to activation of MAPKs and STAT3, which in turn induced expression of EMT-related genes, including Twist1, N-cadherin, Snail1, and vimentin [187]. STAT3 inhibition in FGFR4-R388 GC cells contributed to decreased vimentin and increased E-cadherin levels, suggesting that the FGFR4-R388/STAT3 pathway plays a key role in EMT of these cells [183]. Interestingly, Whittle and co-workers showed that degradation and internalization of the FGFR4-R388 is slower than that observed for FGFR4-G388 [188]. One mechanism may be the formation of a complex of FGFR4-R388 variant with membrane type 1 matrix metalloproteinase (MT1-MMP) (Figure 3), which controls many cellular functions through proteolytic and non-proteolytic interactions with membrane-associated proteins [189]. MT1-MMP has been identified as a mediator of chemoresistance and modulator of DNA damage response in breast cancer [190]. The MT1-MMP/FGFR4-R388 interaction was found to increase MT1-MMP phosphorylation, endosomal stabilization, and decrease lysosomal degradation of MT1-MMP, which in turn 
enhances FGFR4-R388 autophosphorylation [189]. Furthermore, increased FGF1-induced MT1-MMP expression was observed in prostate cancer and was found to be dependent on the STAT3 pathway [191]. In another study, the expression of MT1-MMP expression in pancreatic cancer cells was induced by FGF10, which was also correlated with increased cell migration and invasion [192]. In contrast, in MCF-7 cells, MT1-MMP exhibited the opposite effect and downregulated FGF2-dependent signaling by attenuating FGF2/FGFR binding [193].

\section{Sensitization of Tumor Cells to Chemotherapy by Inhibition of FGF/FGFR Complex Activity}

Mutations and alterations on the FGF-FGFR axis have been reported in many, including resistant, cancer types. Therefore, a new opportunity to develop personalized therapy based on FGFR-targeting has emerged. In recent years, tremendous progress has been made in modulating or correcting aberrant FGF/FGFR signaling [12,105,194,195]. Such a strategy includes the application of receptor inhibitors, ligand traps, monoclonal antibodies, microRNAs, and combination therapy (Figure 4) [12,105,194-196].

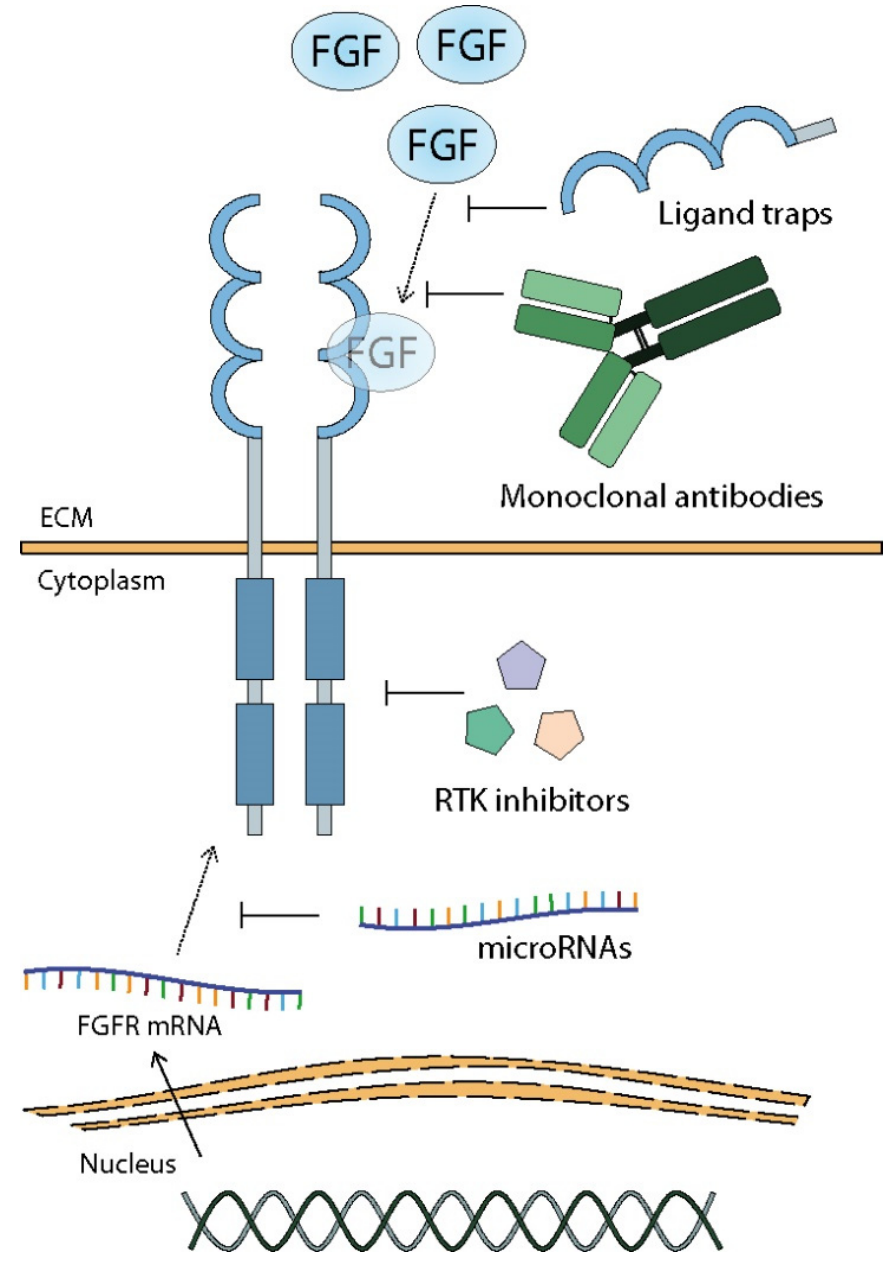

Figure 4. Anti-cancer therapy strategies based on targeting of FGF/FGFR. Ligand traps are fusion molecules that prevent FGF binding and subsequent receptor dimerization. Monoclonal antibodies neutralize specific members of the FGF family members. Chemical receptor tyrosine kinase inhibitors (TKi) are able to inhibit FGFR activation and phosphorylation. Finally, microRNA molecules are capable of silencing both oncogenes and tumor suppressors. Targeting the FGF/FGFR axis with these agents may hold promise for anti-cancer treatment, including overcoming chemoresistance. 


\subsection{TK Inhibitors}

Currently, some TKIs have been developed to inhibit FGFR, that can be divided into two groups: (i) non-selective FGFR TKIs, targeting a wide range of tyrosine kinases, including FGFR, and (ii) selective FGFR TKIs, targeting specifically the FGFR group (Table 2) [194-197]. AZD4547, as an example of the second group, exhibits pro-apoptotic and anti-proliferative activity in cell lines with deregulated FGFR expression, such as KG1a (acute myeloid leukemia line), Sum52-PE (breast cancer cell line), and KMS11 (multiple myeloma line) [198]. Simultaneous treatment with AZD4547 and PLX51107 (BET inhibitor) was shown to counteract FGF2-induced resistance to PLX51107 and to suppress the growth of uveal melanoma tumors [199]. Simultaneous treatment of NSCLC cells with AZD4547 and gefitinib prevented the formation of gefitinib-resistant clones [82]. Similarly, PD173074 was shown to re-sensitize NSCLC to gefitinib treatment [83] and esophageal squamous cell carcinoma (ESCC) to lapatinib treatment [200]. It was also able to prevent proliferation of SCLC lines (H-510 and H-69) in a dose-dependent manner and counteracted FGF2-induced resistance to cisplatin [201]. In HNSCC cells resistant to bevacizumab or pemetrexed-resistant lung adenocarcinoma cells, PD173074 showed potent inhibition of tumor growth and re-sensitization of cancer cells to these drugs [53,176]. Additionally, PD173074 also potentiated the effect of doxorubicin and paclitaxel in endometrial cancer cells carrying a mutation in FGFR2 [202]. Treatment of ER+ breast cancer cells with FGFR inhibitors AZD4547 and PD173074 sensitized the cells to the anti-estrogen tamoxifen suggesting that targeting FGF10/FGFR2 may be a new approach to overcome resistance to hormone-deprivation therapy [203].

Furthermore, PD173074 was able to downregulate P-gp (P-glycoprotein 1) and MRP7 (multidrug resistance protein 7), which in turn increased drug accumulation inside cancer cells and enhanced the toxicity of drugs, such as paclitaxel or vincristine [204,205]. Two other FGFR inhibitors, erdafitinib (JNJ-42756493) and ASP5878, can also re-sensitize cancer cells overexpressing P-gp to anti-cancer drugs $[153,206]$. However, it is still unclear whether the effect of erdafitinib is solely due to FGFR inhibition, as further analysis revealed an interaction between the inhibitor and P-gp [206,207]. ASP5878 was confirmed to have a clinical potential in the treatment of urothelial cancers expressing mutated FGFR3, including gemcitabine- and doxorubicin (adriamycin)-resistant forms [153]. ASP5878 reduced c-MYC protein level in both parental and gemcitabine-resistant urothelial cancer cell lines, suggesting that c-MYC expression may be regulated by the FGFR signaling [153]. Recent studies on lung cancer revealed that c-MYC is a key downstream effector of FGF/FGFR-dependent signaling in response to oxidative stress, and that FGFR inhibition induced apoptosis through c-MYC downregulation [152]. Interestingly, co-expression of FGFR1 and c-MYC resulted in higher sensitivity to FGFR inhibitors [154]. Another interesting compound is infigratinib (BGJ398), which is a selective pan-FGFR inhibitor and a potent anti-cancer drug candidate [208-210]. Inhibition of FGFR by BGJ398 resulted in inactivation of AKT and STAT3 and reduced viability of SKOV3ip1 ovarian carcinoma cells [208]. Treatment with BGJ398 enhanced the cytotoxic effect of paclitaxel/carboplatin cytotoxic activity in ovarian carcinoma cells [208]. A similar effect was observed for alofanib, an allosteric FGFR2 inhibitor [211]. The administration of BGJ398 reduced cell viability and enhanced apoptosis in GIST (gastrointestinal stromal tumor) T-1 cell line resistant to imatinib, but not in parental cells [46]. In GIST cells resistant to doxorubicin, the administration of BGJ398 resulted in a delay in DNA repair [212]. BGJ398 was also found to reduce cell viability, induce apoptosis, and increase the cytotoxicity of 5-fluorouracil or oxaliplatin in CRC cells [52]. Simultaneous treatment of EGFR-positive mesenchymal cancer with BGJ398 and an EGFR inhibitor overcame EGFR inhibitor insensitivity by elimination of EGFR mutant drug-tolerant cells, preventing EMT-associated resistance in both in vitro and in vivo models [213]. Another FGFRs inhibitor, LY2874455, re-sensitizes BRAF-mutant melanoma cells to vemurafenib [47]. A study in drug-resistant gastric cancer cell lines revealed that the specific FGFR2 inhibitor, Ki23057, restored the sensitivity of these cells to irinotecan, paclitaxel, and etoposide, but not to oxaliplatin or gemcitabine [214]. The effect 
of Ki23057 was accompanied by a decrease in ERCC1 (excision repair-cross complementing gene 1) expression level, and an increase in p53 expression level [214].

\subsection{Monoclonal Antibodies and Ligand Traps}

Two classes of drugs associated with FGF/FGFR inhibition, monoclonal antibodies (mAbs) and FGF-ligand traps, characterized by lower toxicity compared to chemical inhibitors, represent an alternative and promising tool in anti-cancer treatment.

The first group, mAbs, are biologically active molecules that bind to a specific target, such as FGFs, FGFRs or even their isoforms, leading to its inactivation [197,215]. Recently, several mAbs directed towards the FGF/FGFR axis have been developed, including burosumab (KRN23), bemarituzumab (FPA144), BAY1179420, MFGR1877S, GAL-F2, R1MAb1 [12]. Bemarituzumab, an mAb targeting FGFR2b that binds specifically to the IgG III region of the receptor, preventing ligand binding and downstream signaling, has been reported to show anti-tumor activity in breast cancer and gastroesophageal adenocarcinoma [12,105]. Furthermore, the mAb MGFR1877S inhibiting FGFR3 dimerization has been shown to have positive results in the treatment of multiple myeloma and solid tumors [12,105]. Additionally, antibodies against FGFR ligands, including anti-FGF2 mAb 3F12E7, and antibodies targeting FGF8b or FGF19, are being investigated as therapeutic approaches to inhibit tumor growth $[12,215]$.

A second, rapidly developing approach uses ligand traps, fusion molecules that prevent the ligand binding to the receptor. Current FGF-targeting drugs include FP-1039 (GSK3052230), SM27, NSC12, sFGFR2IIIc, sFGFR3, and peptide P3 [12,105]. For example, FP-1039 is an FGF-ligand trap that consists of the extracellular domain of FGFR1 fused to the Fc region of IgG1, capable of binding and neutralizing multiple FGFs such as FGF1, FGF2, and FGF4 [12,197,215-217]. This ligand trap has been shown to be able to block FGF2dependent cell proliferation and inhibit the growth of several cancers in xenograft models, including FGFR1-amplified lung cancer and FGF2-overexpressing mesothelioma [216]. In addition, FP-1039 reduces plasma level of FGF2 in cancer patients in whom standard therapy has been ineffective [216]. Another example is NSC12, which in addition to being a trap for multiple FGFs, can also modulate the formation of FGF/FGFR complex with heparan sulphate proteoglycans, and has been linked to inhibition of lung cancer growth and metastasis [12].

As mAbs and ligand traps are relatively new forms of anti-cancer drugs and their clinical application is limited, there are no reports to date of their action in counteracting drug resistance. However, suramin, a small-molecule compound that acts similarly to ligand traps by preventing growth factors, including FGFs, from binding to receptors $[29,218,219]$, has been shown to significantly reverse FGF-induced resistance and enhance the anti-tumor effect of doxorubicin in the human prostate PC3 cancer model, leading to complete inhibition of tumor growth [218]. It should be mentioned here that another study in NSCLC patients receiving paclitaxel or carboplatin did not confirm the positive effect of suramin (at non-toxic doses) on tumor sensitization to treatment [220].

\subsection{MicroRNAs}

A new approach to anti-cancer therapy and overcoming drug resistance is the administration of microRNAs (miRNAs) [221]. In cancer progression and the development of drug resistance, specific miRNAs, which regulate various cellular processes by silencing the expression of genes, both oncogenes and tumor suppressors, may be down- or upregulated [221-223]. For example, miR-205, an FGF2- and VEGFA-targeting molecule that negatively regulates their expression, is highly expressed in breast cancer sensitive to TAC (taxol, doxorubicin, cyclophosphamide) chemotherapy, in contrast to drug-resistance cell lines, in which miR-205 is downregulated [223]. In temozolomide-resistant glioma cells, upregulation of FGFR1 was found to cooperate with downregulation of miR-3116, a molecule silencing the FGFR1 [57]. Re-introduction of miR-3116 resulted in the decrease in FGFR1 level, inhibited the PI3K/AKT pathway, and re-sensitized cancer cells to treatment [57]. 
All abovementioned strategies strongly demonstrate that targeting the FGF/FGFR axis by different classes of molecules may be a promising strategy for cancer treatment, reducing cancer cell growth, and overcoming chemoresistance (Table 2).

Table 2. Anti-cancer strategies overcoming drug-resistance in FGFR-positive tumors.

\begin{tabular}{|c|c|c|c|c|}
\hline Class of Drug & Name & Eliminating Resistance to & Cancer Type & References \\
\hline \multirow{25}{*}{ Chemical inhibitors } & \multirow{3}{*}{ AZD4547 } & Gefitinib & NSCLC & [82] \\
\hline & & PLX51107 & Melanoma & [199] \\
\hline & & Tamoxifen & Breast cancer & [203] \\
\hline & \multirow{8}{*}{ PD173074 } & Gefitinib & NSCLC & [83] \\
\hline & & Lapatinib & ESCC & [200] \\
\hline & & Cisplatin & SCLC & [201] \\
\hline & & Bevacizumab & HNSCC & [53] \\
\hline & & Pemetrexed & Lung cancer & [176] \\
\hline & & Doxorubicin & Endometrial cancer & [202] \\
\hline & & Paclitaxel & NSCLC & [205] \\
\hline & & Vincristine & \multirow{2}{*}{ Epidermoid carcinoma } & [204] \\
\hline & $\begin{array}{c}\text { Erdafitinib } \\
\text { (JNJ-42756493) }\end{array}$ & Colchicine & & [206] \\
\hline & \multirow{2}{*}{ ASP5878 } & Gemcitabine & \multirow{2}{*}{ Urothelial cancer } & \multirow{2}{*}{ [153] } \\
\hline & & Doxorubicin & & \\
\hline & \multirow{6}{*}{ BGJ398 (Infigratinib) } & Paclitaxel/carboplatin & Ovarian cancer & [208] \\
\hline & & 5-fluorouracil & \multirow{2}{*}{ Colorectal cancer } & \multirow{2}{*}{ [52] } \\
\hline & & Oxaliplatin & & \\
\hline & & Imatinib & \multirow{2}{*}{ GIST } & [46] \\
\hline & & Doxorubicin & & [212] \\
\hline & & Gefitinib & NSCLC & [213] \\
\hline & Alofanib & Paclitaxel/carboplatin & Ovarian cancer & [211] \\
\hline & LY2874455 & Vemurafenib & Melanoma & [47] \\
\hline & \multirow{3}{*}{ Ki23057 } & Irinotecan & \multirow{3}{*}{ Gastric cancer } & \multirow{3}{*}{ [214] } \\
\hline & & Paclitaxel & & \\
\hline & & Etoposide & & \\
\hline Ligand trap & Suramin & Doxorubicin & Prostate cancer & [218] \\
\hline \multirow{2}{*}{ miRNAs } & miR-205 & $\begin{array}{l}\text { Paclitaxel/doxorubicin/ } \\
\text { cyclophosphamide }\end{array}$ & Breast cancer & [223] \\
\hline & $\operatorname{miR}-3116$ & Temozolomide & Glioma & [57] \\
\hline
\end{tabular}

\section{Limitations of FGFR Inhibition Therapy-FGFR Mutations and Molecular} Cross-Talks with Other Protein

Despite the proven anti-tumor activity of FGFRs inhibitors, the emergence of new mutations must be taken into account, as well as the existence of molecular cross-talk between the FGFs/FGFRs axis and other proteins, especially other RTK (Figure 5). 


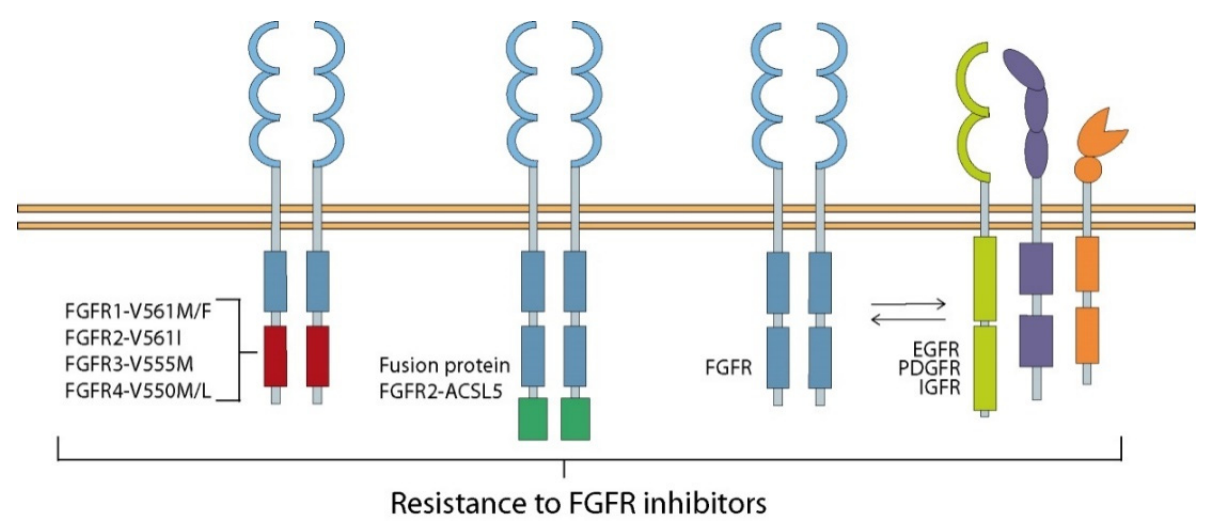

Figure 5. Mutations and molecular cross-talks in the acquisition of resistance to FGFR inhibitors. The use of TKIs in cancer cells expressing FGFRs leads to the acquisition of gatekeeper mutations in the FGFR kinase domain (FGFR1-V561M/F, FGFR2-V561I, FGFR3-V555M, and FGFR4-V550M/L), which in turn desensitize cells to the inhibitor used and may also induce cross-resistance to other inhibitors. FGFR2-ASCL5 fusion leads to the development of resistance to LY2874455, an FGFR inhibitor that overcomes resistance caused by gatekeeper mutations. FGFR inhibition can also lead to the activation of other RTKs, including EGFR, PDGFR, and IGFR, which alternatively trigger downstream cell signaling and render cells insensitive to TKIs.

Clinical trials have shown that a significant fraction of patients with FGFR-positive tumors do not respond to treatment with FGFRs inhibitors [224,225]. Mutations located in ATP-binding sites of the kinase domain of FGFR have been shown to be a common cause of inhibitor resistance in FGFR-dependent tumors, especially gatekeeper mutation resulting in increased receptor activity [195,196,226-228]. Generated gatekeeper FGFR3V555M mutation in KMS-11 myeloma cells with acquired resistance to AZ12908010 caused cross-resistance to two other FGFR inhibitors, AZD4547 and PD173074 [227]. Byron and co-workers identified 14 mutations in the FGFR2 kinase domain responsible for resistance to dovitinib, which with one exception also provided cross-resistance to PD173074 but not to ponatinib [226]. Only the gatekeeper FGFR2-V565I mutation confers resistance to both inhibitors. A similar mutation was observed for FGFR1 (FGFR1-V561M) in lung cancer, which drives resistance to AZD4547 through the activation of STAT3 and EMT [229]. However, a third generation FGFR inhibitor, GZD824, overcomes resistance caused by FGFR1-V561M/F mutation [230]. Point mutations in the FGFR2 kinase domain were also found in FGFR2 fusion-positive intrahepatic cholangiocarcinoma (ICC) [231,232]. FGFR2 gene fusions with BICC1, AHCYL1, TACC3, MGEA5, and PPHLN1 result in chimeric proteins that can dimerize and activate independently of ligand binding but are still sensitive to FGFR inhibitors.

Recently, clinical trials have also shown a positive effect in ICC patients after treatment with BGJ398 [231]. Unfortunately, in some patients the acquisition of secondary mutations has led to further tumor progression and drug resistance [231,233]. However, additional studies in ICC patients resistant to BGJ398 revealed that an irreversible FGFR inhibitor, TAS-120, eradicated drug resistance [233]. Additionally, in a myeloma cell line resistant to AZ12908010 with a gatekeeper mutation in the FGFR3 gene, a secondary gatekeeper mutation was identified, resulting in the development of cross-resistance to two other FGFR inhibitors, AZD4547 and PD173074 [227]. Gatekeeper mutations in the kinase domain (V550) and hinge-1 (C552) of FGFR4 are acquired as a mechanism of resistance to fisogantib, a selective FGFR4 inhibitor, in HCC [41]. Interestingly, a gatekeeper-agnostic, LY2874455, decreased HCC xenograft growth in the presence of these mutations, demonstrating continued FGF19-FGFR4 pathway dependence [41]. Moreover, FGFR2-ACSL5 fusion, newly identified in GC, led to acquired resistance to LY2874455, highlighting the need to study FGFR2 amplification in terms of developing drug resistance [234]. 
Another noteworthy aspect is the interaction between FGF/FGFR and other proteins, which may serve cancer cells as an alternative to activate mutagenic cell signaling pathways, including by passing the action of FGFR inhibitors. FGFRs have been identified as copartners for many cell membrane-associated proteins, including RTKs and G-proteincoupled receptors (GPCRs) [235]. Adachi and co-workers identified a role for other receptor tyrosine kinases such as EGFR, PDGFR $\alpha$ (platelet-derived growth factor receptor $\alpha$ ), and IGFR (insulin-like growth factor receptor) in the emergence of resistance to FGFR inhibitor treatment in FGFR1-amplified lung cancer [236]. Combination therapy of BGJ398 with lapatinib in the HCC95 cell line or with linsitinib (an IGFR inhibitor) in the DMS114 cell line was necessary for the downregulation of FRS2 $\alpha$ to suppress reactivation of both AKT and ERK and the subsequent induction of apoptotic proteins BIM and PUMA (p53 upregulated modulator of apoptosis) [236]. Interestingly, the acquisition of resistance to BGJ398 in DMS114 cells and urothelial carcinoma cells (RT112) was mediated by the AKT pathway [237]. Monotherapy of BGJ398 or imatinib, a PDGFR inhibitor, resulted in phosphorylation of the second receptor and activation of the downstream MAPK pathway, and only administration of both drugs induced complete inactivation of ERK, indicating an interaction between these receptors, which was confirmed by pull-down [236]. Similarly, in FGFR2-positive GC, resistance to AZD4547 was abolished by EGFR, HER3, or MET inhibition, indicating that these other RTKs are responsible for cancer cell resistance to FGFR inhibition [238]. Acquisition of resistance to infigratinib, a promising FGFR inhibitor used to treat HCC, was associated with elevated HER2 and HER3 levels along with increased enhancer of zeste homolog 2 (EZH2) expression [239]. In HER2-positive breast cancer cells with EMT, resistance to HER2 inhibitor was mediated by increased expression and direct interaction of FGFR1 and neuropilin-1 (NRP1) [175]. Silencing of NRP1 reduced FGF2-dependent ERK activation and inhibited cancer cell growth [175]. Interestingly, NRP1 expression and subsequent drug resistance was mediated by two EMT-related transcription factors, Twist1 and BRD4 [175]. A study by Wang and colleagues linked the activation of HER2/3 to the development of resistance to FGFR inhibitors such as BGJ398 and ponatinib in cell lines harboring FGFR3 amplification [240]. Moreover, FGFR3 was also found as one of the fusion proteins that cause acquired resistance to EGFR inhibitors in lung cancer patients [241].

Another study has shown that the expression of FGF2 by human melanoma cells mediated the promotion of tumor-associated B (TAB) cells to express IGF1 [34]. Co-culture of melanoma cells with TAB cells, but not normal $B$ cells, led to the development of resistance to BRAF and MEK inhibitors as well as cisplatin and paclitaxel treatment. The expression of IGF1 mediated upregulation of FGFR3 and STAT3 in both TAB and melanoma cells. The silencing of IGF1 re-sensitized melanoma cells to BRAF/MEK inhibition, suggesting that IGF1 plays a major role in developing drug resistance in that case. Interestingly, the deactivation of FGFR3 was also able to overcome the resistance indicting the correlation between IGF1 and FGFR3 in the chemoresistance in human melanoma cells. Another notable mechanism of drug resistance related to the FGFR family is that overexpression of FGFRL1 (fibroblast growth factor receptor-like 1) was found in patients with multidrug resistance SCLC [242]. Although FGFRL1 lacks the kinase domain, there is some evidence indicating the role of FGFRL1 in the regulation of FGF signaling pathways and cancer progression [242-244]. In SCLC cells, FGFRL1 was found to interact with ENO1 (alpha-enolase), a protein involved in activation of the PI3K/AKT pathway in tumors, therefore FGFRL1 might modulate drug resistance in SCLC cells [242]. Additionally, it was demonstrated that knockdown of androgen receptor mediated prostate tumor-inducing response of paracrine FGF10, suggesting the role of tumor environment in the initiation of carcinomas and underlying its importance as well as its implications in the development of treatment strategies [245]. 


\section{Enhancement of Chemotherapy by FGFs/FGFRs Action}

The protective properties of FGFs and their receptors have been widely described, nevertheless, several lines of evidence point to their opposing effects. Ohashi and co-workers found a correlation of FGFR2 lower expression with increased cancer cell proliferation and poor prognosis in patients with gliomas [19]. In MCF-7 breast cancer cells, FGF2 not only inhibited cell growth and proliferation but also potentiated the effects of anti-cancer drugs by downregulation of BCL2 and upregulation of BAX level, thereby enhancing apoptosis [246,247]. Coleman and co-workers suggested that FGF2-induced sensitization to anti-cancer treatment is independent of increased proliferation, S-phase of cell cycle, or p53 activity [248]. FGF2, but not FGF1, was shown to enhance cisplatin toxicity in MCF-7 breast cancer cells and A2780 ovarian cancer cells, but not in SKOV3 ovarian cancer cells or a panel of pancreatic cancer cell lines. In this work, FGF2 did not sensitize cells to etoposide, however, in the other study Wang and co-worker observed reduced colony formation and increased apoptosis in MCF-7 cells induced by FGF2 upon treatment with etoposide or 5-fluorouracil [247,248]. Moreover, in the mouse myoblast cell line C2C12, FGF2 through NFKB activity, but not the PI3K pathway, increased the expression of uridine phosphorylase 1 , the enzyme that activates 5-fluorouracil, which was correlated with enhanced toxicity of the drug [249].

In another study, the interaction of FGFR4 with the $\beta$ Klotho (KLB) co-receptor, a metabolic regulator that is frequently disrupted in hepatic cancers, was shown to inhibit cell proliferation and induce caspase-3-dependent apoptosis in hepatomas by decreasing AKT and mTOR activity [250]. Similarly, KLB expression was downregulated in prostate cancer cells, whereas its overexpression was able to induce apoptosis, inhibit cell proliferation and reverse androgen receptor-dependent and -independent EMT [251]. Furthermore, in breast cancer patients receiving radiochemotherapy (5-fluorouracil, vinorelbine, radiotherapy), FGFR1 expression correlated with good response to treatment, whereas FGFR1-negative cancers showed resistance to this treatment [252]. Additionally, the reduced FGF14 level was correlated with poor survival and oncogenic mutation status (e.g., KRAS, EGFR) in lung adenocarcinoma (LUAC) patients [253]. Overexpression of FGF14 in NSCLC LUAC cell line (A549) resulted in decreased proliferation, colony formation and migration, and enhanced mesenchymal to epithelial transition, indicating that FGF14 reduces the invasiveness of lung cancer cells in vitro while ablation of FGF14 in these cells reversed the above changes, supporting its suppressive role in lung cancer progression. Furthermore, RNA sequencing data suggested that genes affected by FGF14 were associated with the extracellular matrix (upregulation of Ccbe1 and Adarb1, downregulation of Coll11a1 and Muc16), and thus could play a role in proliferation and migration. Therefore, therapeutics activating the tumor suppressive properties of FGF14 would be a promising strategy for the treatment of LUAC patients.

\section{Concluding Remarks}

Due to multiple critical biological activities, the FGF/FGFR axis plays an important role in cancer growth and progression. Chromosomal abnormalities often lead to overexpression of FGFs and their receptors, formation of fusion proteins, and generation of constitutively active kinase domains that can deregulate downstream signaling and further promote uncontrolled proliferation, apoptosis avoidance, and metastasis. However, the role of FGF/FGFR in carcinogenesis extends beyond cancer development and progression, as increasing evidence suggests a close link between FGF/FGFR signaling and the failures of various currently available anti-cancer therapies. To date, several distinct mechanisms of FGF/FGFR-mediated anti-cancer drug resistance have been described, but the picture is far from complete, highlighting the need for further studies in this field.

Although many drugs (such as paclitaxel, cisplatin, etoposide, or doxorubicin) show promising anti-cancer activity, the acquisition of drug resistance complicates the treatment. The reduced responses to therapeutic agents have been associated with the deregulation of several signaling pathways, such as PI3K/AKT, MAPKs, STATs, and PLC $\gamma /$ PKC, which can 
be activated by FGF/FGFR. Not only mutations in signaling proteins and aberrant signal transduction, but also cross-talks with other pathways are major obstacles to overcome acquired resistance. Abnormalities in signal transduction can lead to deregulation of biological process such as apoptosis (through an imbalance between its inhibitors and activators), angiogenesis (through an increase in VEGF expression), and EMT (through disproportion in expression between epithelial and mesenchymal markers), making the development of effective therapy even more challenging [105].

In addition to canonical FGFs, other members of the FGF family may be involved in the acquisition of drug resistance by cancer cells. For example, FGF13, a representative of intracrine FGFs, has been found to contribute to the insensitivity of cervical cancer cells to cisplatin [38]. Recent studies have shown that also FGF12 has anti-apoptotic properties in the osteosarcoma U2OS cell line overexpressing FGFR1 (U2OS-R1), but this has not yet been linked to drug resistance [254].

The interference of multiple factors can result in an impaired cellular response to anti-cancer treatment. For instance, tumor heterogeneity may lead to the development of different drug sensitivities in individual cells as well as the evolution of more resistant clones. Another aspect is the diverse microenvironment of cancer cells, where the presence of various cytokines, growth factors, and extracellular matrix compounds, often derived from CAFs, may cause additional changes in cellular metabolism.

Deregulated metabolism can drive further mutations (e.g., gatekeeper mutations in kinase domain of FGFR) leading to cross-resistance and thus to the ineffectiveness of even the most specialized strategies [195,196,226-228]. On the other hand, reports of positive effects of FGF/FGFR on chemotherapy further emphasize the complexity of the whole system [246-248].

Finally, interactions of FGF receptors with other proteins, including RTKs, and crossactivation between proteins from independent signaling pathways might prevent effective therapy. A good example is the interaction of FGF/FGFR complex with galectins, which constitute a family of carbohydrate binding proteins that modulate many critical cellular processes [255]. In recent years, galectins have emerged as major determinants of tumor sensitivity or resistance to various anti-cancer therapies [256]. Importantly, the involvement of galectins in the FGF/FGFR signaling was suggested several years ago [257]. We have recently shown that extracellular galectin-1 activates FGFR1 and thereby stimulates cell proliferation and apoptosis avoidance [258]. In addition, galectins may facilitate cross-talk of FGFRs with themselves [259]. The role of galectins in FGFR-dependent chemoresistance has not been demonstrated yet. Since FGFRs and galectins are involved in diverse mechanisms of chemoresistance, it is tempting to speculate that these two groups of proteins, may form a complex network modulating tumor sensitivity to various anti-cancer drugs.

Targeted therapy based on modulation of FGF/FGFR activity using ligand traps, monoclonal antibodies, RTK inhibitors, and microRNAs offers promising, effective therapeutic approaches. Several studies on FGF/FGFR inhibition have demonstrated its efficacy in re-sensitizing cells to treatment. Another interesting therapeutic option to overcome resistance to TK inhibitors is the disruption of lysosome architecture to release sequestrated TK inhibitors [196]. Similarly, the concomitant use of inhibitors to abolish drug resistance has been shown to be more effective in clinical trials [194,260]. Another promising strategy is combination therapy with TKIs and signaling pathway inhibitors [194,237,261,262], as well as simultaneous inhibition of FGFRs and induction of apoptosis [263-265]. Ligand traps and mAbs targeting FGFR/FGF are relatively new approaches and are still relatively few in clinical trials. However, they appear tohave great potential to overcome drug resistance, particularly when combined with other therapies, including inhibitor treatment, radiotherapy, or chemotherapy.

In recent years, antibody-drug conjugates (ADCs) have emerged as a precise and powerful tool in cancer treatment [266]. These bioconjugates consist of an $\mathrm{mAb}$ that specifically binds a tumor surface antigen and a potent drug, such as monomethylauristatin E, calicheamicin, maytansinoid, or camptothecin [267]. To date, 12 ADCs have been approved 
by Food and Drug Administration as therapeutics for oncology indications, and many more are currently under investigation [267]. Nevertheless, they usually contain a single cytotoxic drug, which can easily lead to the development of chemoresistance. Therefore, dual-drug conjugates, with two distinct mechanisms of action, showing enhanced efficacy and hindering the development of drug resistance, appear to be the future of anti-cancer strategies [268,269].

Moreover, endocytosis and RTK signaling are closely connected, also in cancer cells [270]. It is plausible that endocytosis, including FGF/FGFR endocytosis, may influence resistance to anti-cancer treatment by modulating the level of FGF/FGFR and/or the specificity and duration of their signaling, and consequently the efficacy of targeted therapies [271-273]. An effective solution could be the generation of targeting molecules that, by exploiting multiple endocytosis routes simultaneously, enable continuous delivery of drugs when cancer cells begin to manipulate endocytosis pathways as a defense mechanism [274].

The multitude of alternative strategies being developed in parallel, and the rapid progress of targeted therapies, bring hope in the field of personalized medicine in overcoming drug resistance in various cancers, including FGFR-dependent ones.

Author Contributions: Conceptualization, J.S. and M.Z.; writing-original draft preparation, J.S., I.M., K.D.S., M.Z.; writing—review and editing, M.Z., J.S., K.D.S., L.O., J.O.; visualization, J.S., K.D.S.; supervision, M.Z.; project administration, M.Z.; funding acquisition, M.Z. All authors have read and agreed to the published version of the manuscript.

Funding: This work was funded by National Science Centre in Poland, grant Sonata Bis 2015/18/E/ NZ3/00501. L.O. was supported by Sonata Bis grant 2019/34/E/NZ3/00014 from the National Science Centre, Poland.

Conflicts of Interest: All authors declare that they have no conflict of interest.

$\begin{array}{ll}\text { Abbreviations } & \\ \text { ADC } & \text { antibody-drug conjugate } \\ \text { BAD } & \text { BCL-2 antagonist of cell death } \\ \text { BAX } & \text { apoptosis regulator BAX } \\ \text { BCL-2 } & \text { B-cell CLL/lymphoma 2 } \\ \text { BCL-XL } & \text { B-cell lymphoma-extra large } \\ \text { BIM } & \text { BCL-2-like protein 11 } \\ \text { BRAF } & \text { serine/threonine-protein kinase B-raf } \\ \text { CAFs } & \text { cancer-associated fibroblasts } \\ \text { CAM } & \text { cell adhesion molecule } \\ \text { CC } & \text { colon cancer } \\ \text { CK2 } & \text { casein kinase 2 } \\ \text { CMF } & \text { cyclophosphamide/methotrexate/5-fluorouracil chemotherapy } \\ \text { CRC } & \text { colorectal cancer } \\ \text { DAG } & \text { diacyloglycerol } \\ \text { E12/E47 } & \text { immunoglobulin enhancer-binding factor lub transcription factor E2-alpha } \\ \text { ECM } & \text { extracellular matrix } \\ \text { EF1/ZEB1 } & \text { elongation factor 1/zinc finger E-box-binding homeobox 1 } \\ \text { EGF } & \text { epithelial growth factor } \\ \text { EGFR } & \text { epithelial growth factor receptor } \\ \text { EMT } & \text { epithelial-to-mesenchymal transition } \\ \text { ENO1 } & \text { alpha-enolase } \\ \text { ER } & \text { estrogen receptor } \\ \text { ERCC1 } & \text { excision repair-cross complementing gene 1 } \\ \text { ERK } & \text { extracellular signal-regulated kinase } \\ \text { ESCC } & \text { esophageal squamous cell carcinoma }\end{array}$




\begin{tabular}{|c|c|}
\hline FGF & fibroblast growth factor \\
\hline FGFR & fibroblast growth factor receptor \\
\hline FGFRL1 & fibroblast growth factor receptor-like 1 \\
\hline ESCC & esophageal squamous cell carcinoma \\
\hline FLIP & FLICE-like inhibitory protein \\
\hline FOXO1 & forkhead box protein $\mathrm{O} 1$ \\
\hline FRA1 & Fos-related antigen 1 \\
\hline FRS $2 \alpha$ & fibroblast growth factor receptor substrate 2 \\
\hline GAB1 & GRB2-associated binding protein 1 \\
\hline GC & gastric cancer \\
\hline GIST & gastrointestinal stromal tumor \\
\hline GPCR & G-protein-coupled receptor \\
\hline GRB2 & growth factor receptor-bound 2 \\
\hline GSK3 $\beta$ & glycogen synthase kinase $3 \beta$ \\
\hline HA & hyaluronan \\
\hline $\mathrm{HER} 2 / 3$ & receptor tyrosine-protein kinase erbB-2/3 \\
\hline HES1 & hairy and enhancer of split1 \\
\hline $\mathrm{HCC}$ & hepatocellular carcinoma \\
\hline HGF & hepatocyte growth factor \\
\hline HNC & head and neck cancer \\
\hline HNSCC & head and neck squamous cell carcinoma \\
\hline $\mathrm{HO}-1$ & hemeoxygenase 1 \\
\hline HSC & hepatic stellate cells \\
\hline HSP90 & heat shock protein 90 \\
\hline IP3 & inositol-1,4,5-triphosphate \\
\hline ICC & intrahepatic cholangiocarcinoma \\
\hline IGF & insulin-like growth factor \\
\hline IGFR & insulin-like growth factor receptor \\
\hline IKK- $\beta$ & inhibitors of $N F \kappa B$ kinase- $\beta$ \\
\hline JAK & Janus kinases \\
\hline JNK & c-Jun N-terminal kinase \\
\hline KLB & $\beta$ Klotho \\
\hline LUAC & lung adenocarcinoma \\
\hline $\mathrm{mAb}$ & monoclonal antibody \\
\hline MACOM & MDS1 and EVI1 complex locus protein EVI1 \\
\hline MAPK & mitogen-activated protein kinases \\
\hline MCL1 & myeloid cell leukemia sequence 1 \\
\hline MDM2 & mouse double minute 2 homolog \\
\hline MEK & mitogen-activated protein kinase kinase \\
\hline MMTV & mouse mammary tumor virus \\
\hline miRNA & microRNA \\
\hline MRP7 & multidrug resistance protein 7 \\
\hline MT1-MMP & membrane type 1 matrix metalloproteinase \\
\hline mTOR & mammalian target of rapamycin \\
\hline mTORC1/2 & mammalian target of rapamycin complex $1 / 2$ \\
\hline NCT & neoadjuvant chemotherapy \\
\hline $\mathrm{NF}_{\kappa} \mathrm{B}$ & nuclear factor- $\kappa \mathrm{B}$ \\
\hline Notch & neurogenic locus notch homolog protein \\
\hline NRP1 & neuropilin-1 \\
\hline Nrf2 & nuclear factor E2-related factor 2 \\
\hline NSCLC & non-small-cell lung cancer \\
\hline P53 & cellular tumor antigen p53 \\
\hline PARP & poly (ADP-ribose) polymerase \\
\hline PD-ECGF & platelet-derived endothelial cell growth factor \\
\hline $\operatorname{PDGFR} \alpha$ & platelet-derived growth factor receptor $\alpha$ \\
\hline P-gp & P-glycoprotein 1 \\
\hline
\end{tabular}




$\begin{array}{ll}\text { PI3K } & \text { phosphoinositide 3-kinase } \\ \text { PIP2 } & \text { phosphatidylinositol-4,5-bisphosphate } \\ \text { PKB } & \text { protein kinase B } \\ \text { PKC } & \text { protein kinase C } \\ \text { PLA2G4C } & \text { phospholipase A2 } \gamma \\ \text { PLC } \gamma & \text { phospholipase C } \gamma \\ \text { PPHLN1 } & \text { periphilin-1 } \\ \text { PRKACB } & \text { cAMP-dependent protein kinase catalytic subunit beta } \\ \text { PUMA } & \text { p53 upregulated modulator of apoptosis } \\ \text { RAP1 } & \text { RAS-proximate-1 or Ras-related protein 1 } \\ \text { RAS } & \text { rat sarcoma virus protein } \\ \text { ROS } & \text { reactive oxygen species } \\ \text { RTK } & \text { receptor tyrosine kinase } \\ \text { S6K2 } & \text { ribosomal p70 S6 kinase 2 (jest teżskrót S6K1) } \\ \text { SCLC } & \text { small cell lung cancer } \\ \text { SIP1/ZEB2 } & \text { smad interacting protein 1/ zinc finger E-box-binding homeobox 2 } \\ \text { SNT-1 } & \text { suc1-associated neurotrophic factor-induced tyrosine-phosphorylated target } \\ \text { SOS1 } & \text { son of sevenless 1 } \\ \text { SOX2 } & \text { Sry-related HMG box 2 } \\ \text { STAT } & \text { signal transducers and activators of transcription } \\ \text { TAB } & \text { tumor-associated B cells } \\ \text { TAC } & \text { taxol, doxorubicin, cyclophosphamide chemotherapy } \\ \text { TGF } \beta & \text { transforming growth factor } \beta \\ \text { Tin-PP } & \text { Tin-Protoporphyrin } \\ \text { TKI } & \text { tyrosine kinase inhibitor } \\ \text { TSC1/2 } & \text { tuberous sclerosis complex } \\ \text { TYK2 } & \text { tyrosine kinase 2 } \\ \text { UPP1 } & \text { uridinephosphorylase 1 } \\ \text { VEGF } & \text { vascular endothelial growth factor } \\ \text { VEGFR } & \text { vascular endothelial growth factor receptor } \\ & \end{array}$

\section{References}

1. Housman, G.; Byler, S.; Heerboth, S.; Lapinska, K.; Longacre, M.; Snyder, N.; Sarkar, S. Drug resistance in cancer: An overview. Cancers 2014, 6, 1769-1792. [CrossRef] [PubMed]

2. Carneiro, B.A.; El-Deiry, W.S. Targeting apoptosis in cancer therapy. Nat. Rev. Clin. Oncol. 2020, 17, 395-417. [CrossRef] [PubMed]

3. Guo, F.; Zhang, H.; Jia, Z.; Cui, M.; Tian, J. Chemoresistance and targeting of growth factors/cytokines signalling pathways: Towards the development of effective therapeutic strategy for endometrial cancer. Am. J. Cancer Res. 2018, 8, 1317-1331. [PubMed]

4. Savant, S.S.; Sriramkumar, S.; O'hagan, H.M. The role of inflammation and inflammatory mediators in the development, progression, metastasis, and chemoresistance of epithelial ovarian cancer. Cancers 2018, 10, 251. [CrossRef]

5. Caetano-Pinto, P.; Jamalpoor, A.; Ham, J.; Goumenou, A.; Mommersteeg, M.; Pijnenburg, D.; Ruijtenbeek, R.; Sanchez-Romero, N.; Van Zelst, B.; Heil, S.G.; et al. Cetuximab Prevents Methotrexate-Induced Cytotoxicity in Vitro through Epidermal Growth Factor Dependent Regulation of Renal Drug Transporters. Mol. Pharm. 2017, 14, 2147-2157. [CrossRef]

6. Min, Y.; Adachi, Y.; Yamamoto, H.; Imsumran, A.; Arimura, Y.; Endo, T.; Hinoda, Y.; Lee, C.T.; Nadaf, S.; Carbone, D.P.; et al. Insulin-like growth factor I receptor blockade enhances chemotherapy and radiation responses and inhibits tumour growth in human gastric cancer xenografts. Gut 2005, 54, 591-600. [CrossRef]

7. Tang, H.; Zeng, L.; Wang, J.; Zhang, X.; Ruan, Q.; Wang, J.; Cui, S.; Yang, D. Reversal of 5-fluorouracil resistance by EGCG is mediate by inactivation of TFAP2A/VEGF signaling pathway and downregulation of MDR-1 and P-gp expression in gastric cancer. Oncotarget 2017, 8, 82842-82853. [CrossRef]

8. Massarweh, S.; Osborne, C.K.; Creighton, C.J.; Qin, L.; Tsimelzon, A.; Huang, S.; Weiss, H.; Rimawi, M.; Schiff, R. Tamoxifen resistance in breast tumors is driven by growth factor receptor signaling with repression of classic estrogen receptor genomic function. Cancer Res. 2008, 68, 826-833. [CrossRef]

9. Ornitz, D.M.; Itoh, N. Fibroblast growth factors. Genome Biol. 2001, 2, 1-12. [CrossRef]

10. Turner, N.; Grose, R. Fibroblast growth factor signalling: From development to cancer. Nat. Rev. Cancer 2010, 10, 116-129. [CrossRef]

11. Ornitz, D.M.; Itoh, N. The fibroblast growth factor signaling pathway. Wiley Interdiscip. Rev. Dev. Biol. 2015, 4, 215-266. [CrossRef]

12. Xie, Y.; Su, N.; Yang, J.; Tan, Q.; Huang, S.; Jin, M.; Ni, Z.; Zhang, B.; Zhang, D.; Luo, F.; et al. FGF/FGFR signaling in health and disease. Signal Transduct. Target. Ther. 2020, 5, 181. [CrossRef] [PubMed]

13. Haugsten, E.M.; Wiedlocha, A.; Olsnes, S.; Wesche, J. Roles of fibroblast growth factor receptors in carcinogenesis. Mol. Cancer Res. 2010, 8, 1439-1452. [CrossRef] [PubMed] 
14. Wesche, J.; Haglund, K.; Haugsten, E.M. Fibroblast growth factors and their receptors in cancer. Biochem. J. 2011, 437, 199-213. [CrossRef] [PubMed]

15. Gospodarowicz, D. Humoral control of cell proliferation: The role of fibroblast growth factor in regeneration, angiogenesis, wound healing, and neoplastic growth. Prog. Clin. Biol. Res. 1976, 9, 1-19. [PubMed]

16. Holley, R.W.; Baldwin, J.H.; Kiernan, J.A.; Messmer, T.O. Control of growth of benzo[a]pyrene transformed 3T3 cells. Proc. Natl. Acad. Sci. USA 1976, 73, 3229-3232. [CrossRef]

17. Baird, A.; Mormède, P.; Böhlen, P. Immunoreactive fibroblast growth factor (FGF) in a transplantable chondrosarcoma: Inhibition of tumor growth by antibodies to FGF. J. Cell. Biochem. 1986, 30, 79-85. [CrossRef]

18. Peters, G.; Lee, A.E.; Dickson, C. Concerted activation of two potential proto-oncogenes in carcinomas induced by mouse mammary tumour virus. Nature 1986, 320, 628-631. [CrossRef]

19. Ohashi, R.; Matsuda, Y.; Ishiwata, T.; Naito, Z. Downregulation of fibroblast growth factor receptor 2 and its isoforms correlates with a high proliferation rate and poor prognosis in high-grade glioma. Oncol. Rep. 2014, 32, 1163-1169. [CrossRef]

20. Colomer, R.; Aparicio, J.; Montero, S.; Guzmán, C.; Larrodera, L.; Cortés-Funes, H. Low levels of basic fibroblast growth factor (bFGF) are associated with a poor prognosis in human breast carcinoma. Br. J. Cancer 1997, 76, 1215-1220. [CrossRef]

21. Jang, J.H.; Shin, K.H.; Park, J.G. Mutations in fibroblast growth factor receptor 2 and fibroblast growth factor receptor 3 genes associated with human gastric and colorectal cancers. Cancer Res. 2001, 61, 3541-3543. [PubMed]

22. Chesi, M.; Nardini, E.; Brents, L.A.; Schrock, E.; Ried, T.; Kuehl, W.M.; Bergsagel, P.L. Frequent translocation t(4;14)(p16.3;q32.3) in multiple myeloma is associated with increased expression and activating mutations of fibroblast growth factor receptor 3 . Nat. Genet. 1997, 16, 260-264. [CrossRef] [PubMed]

23. Shoji, H.; Yamada, Y.; Okita, N.; Takashima, A.; Honma, Y.; Iwasa, S.; Kato, K.; Hamaguchi, T.; Shimada, Y. Amplification of FGFR2 gene in patients with advanced gastric cancer receiving chemotherapy: Prevalence and prognostic significance. Anticancer Res. 2015, 35, 5055-5062. [PubMed]

24. Seo, A.N.; Jin, Y.; Lee, H.J.; Sun, P.L.; Kim, H.; Jheon, S.; Kim, K.; Lee, C.T.; Chung, J.H. FGFR1 amplification is associated with poor prognosis and smoking in non-small-cell lung cancer. Virchows Arch. 2014, 465, 547-558. [CrossRef]

25. Pecqueux, C.; Arslan, A.; Heller, M.; Falkenstein, M.; Kaczorowski, A.; Tolstov, Y.; Sültmann, H.; Grüllich, C.; Herpel, E.; Duensing, A.; et al. FGF-2 is a driving force for chromosomal instability and a stromal factor associated with adverse clinico-pathological features in prostate cancer. Urol. Oncol. Semin. Orig. Investig. 2018, 36, 365.e15-365.e26. [CrossRef]

26. Menzel, T.; Rahman, Z.; Calleja, E.; White, K.; Wilson, E.L.; Wieder, R.; Gabrilove, J. Elevated intracellular level of basic fibroblast growth factor correlates with stage of chronic lymphocytic leukemia and is associated with resistance to fludarabine. Blood 1996, 87, 1056-1063. [CrossRef]

27. Miyake, H.; Hara, I.; Gohji, K.; Yoshimura, K.; Arakawa, S.; Kamidono, S. Expression of basic fibroblast growth factor is associated with resistance to cisplatin in a human bladder cancer cell line. Cancer Lett. 1998, 123, 121-126. [CrossRef]

28. Hsieh, M.J.; Huang, C.; Lin, C.C.; Tang, C.H.; Lin, C.Y.; Lee, I.N.; Huang, H.C.; Chen, J.C. Basic fibroblast growth factor promotes doxorubicin resistance in chondrosarcoma cells by affecting XRCC5 expression. Mol. Carcinog. 2020, 59, 293-303. [CrossRef]

29. Song, S.; Guillaume Wientjes, M.; Gan, Y.; Au, J.L.S. Fibroblast growth factors: An epigenetic mechanism of broad spectrum resistance to anticancer drugs. Proc. Natl. Acad. Sci. USA 2000, 97, 8658-8663. [CrossRef]

30. Vandermoere, F.; Yazidi-Belkoura, I.E.; Adriaenssens, E.; Lemoine, J.; Hondermarck, H. The antiapoptotic effect of fibroblast growth factor- 2 is mediated through nuclear factor- $\kappa B$ activation induced via interaction between Akt and IкB kinase- $\beta$ in breast cancer cells. Oncogene 2005, 24, 5482-5491. [CrossRef]

31. Gan, Y.; Wientjes, M.G.; Au, J.L.S. Expression of basic fibroblast growth factor correlates with resistance to paclitaxel in human patient tumors. Pharm. Res. 2006, 23, 1324-1331. [CrossRef]

32. Smith, G.; Ng, M.T.H.; Shepherd, L.; Herrington, C.S.; Gourley, C.; Ferguson, M.J.; Wolf, C.R. Individuality in FGF1 expression significantly influences platinum resistance and progression-free survival in ovarian cancer. Br. J. Cancer 2012, 107, 1327-1336. [CrossRef]

33. Dorman, S.N.; Baranova, K.; Knoll, J.H.M.; Urquhart, B.L.; Mariani, G.; Carcangiu, M.L.; Rogan, P.K. Genomic signatures for paclitaxel and gemcitabine resistance in breast cancer derived by machine learning. Mol. Oncol. 2016, 10, 85-100. [CrossRef]

34. Somasundaram, R.; Zhang, G.; Fukunaga-Kalabis, M.; Perego, M.; Krepler, C.; Xu, X.; Wagner, C.; Hristova, D.; Zhang, J.; Tian, T.; et al. Tumor-associated B-cells induce tumor heterogeneity and therapy resistance. Nat. Commun. 2017, 8, 1-16. [CrossRef]

35. McDermott, S.C.; Rodriguez-Ramirez, C.; McDermott, S.P.; Wicha, M.S.; Nör, J.E. FGFR signaling regulates resistance of head and neck cancer stem cells to cisplatin. Oncotarget 2018, 9, 25148-25165. [CrossRef]

36. He, L.; Meng, Y.; Zhang, Z.; Liu, Y.; Wang, X. Downregulation of basic fibroblast growth factor increases cisplatin sensitivity in A549 non-small cell lung cancer cells. J. Cancer Res. Ther. 2018, 14, 1519-1524. [PubMed]

37. Makondi, P.T.; Chu, C.-M.; Wei, P.-L.; Chang, Y.-J. Prediction of novel target genes and pathways involved in irinotecan-resistant colorectal cancer. PLoS ONE 2017, 12, e0180616. [CrossRef]

38. Okada, T.; Murata, K.; Hirose, R.; Matsuda, C.; Komatsu, T.; Ikekita, M.; Nakawatari, M.; Nakayama, F.; Wakatsuki, M.; Ohno, T.; et al. Upregulated expression of FGF13/FHF2 mediates resistance to platinum drugs in cervical cancer cells. Sci. Rep. 2013, 3, 2899. [CrossRef] [PubMed]

39. Gao, L.; Wang, X.; Tang, Y.; Huang, S.; Hu, C.A.A.; Teng, Y. FGF19/FGFR4 signaling contributes to the resistance of hepatocellular carcinoma to sorafenib. J. Exp. Clin. Cancer Res. 2017, 36, 1-10. [CrossRef] 
40. Cazet, A.S.; Hui, M.N.; Elsworth, B.L.; Wu, S.Z.; Roden, D.; Chan, C.L.; Skhinas, J.N.; Collot, R.; Yang, J.; Harvey, K.; et al. Targeting stromal remodeling and cancer stem cell plasticity overcomes chemoresistance in triple negative breast cancer. Nat. Commun. 2018, 9, 1-18. [CrossRef] [PubMed]

41. Hatlen, M.A.; Schmidt-Kittler, O.; Sherwin, C.A.; Rozsahegyi, E.; Rubin, N.; Sheets, M.P.; Kim, J.L.; Miduturu, C.; Bifulco, N.; Brooijmans, N.; et al. Acquired on-target clinical resistance validates fgfr4 as a driver of hepatocellular carcinoma. Cancer Discov. 2019, 9, 1686-1695. [CrossRef]

42. Seitz, T.; Freese, K.; Dietrich, P.; Thasler, W.E.; Bosserhoff, A.; Hellerbrand, C. Fibroblast Growth Factor 9 is expressed by activated hepatic stellate cells and promotes progression of hepatocellular carcinoma. Sci. Rep. 2020, 10, 1-9.

43. Hanker, A.B.; Garrett, J.T.; Estrada, M.V.; Moore, P.D.; Ericsson, P.G.; Koch, J.P.; Langley, E.; Singh, S.; Kim, P.S.; Frampton, G.M.; et al. HER2-Overexpressing Breast Cancers Amplify FGFR Signaling upon Acquisition of Resistance to Dual Therapeutic Blockade of HER2. Clin. Cancer Res. 2017, 23, 4323-4334. [CrossRef]

44. Yu, H.; Wang, H.; Qie, A.; Wang, J.; Liu, Y.; Gu, G.; Yang, J.; Zhang, H.; Pan, W.; Tian, Z.; et al. FGF13 enhances resistance to platinum drugs by regulating hCTR1 and ATP7A via a microtubule-stabilizing effect. Cancer Sci. 2021, 112, 4655-4668. [CrossRef] [PubMed]

45. Gammelgaard, K.R.; Vad-Nielsen, J.; Clement, M.S.; Weiss, S.; Daugaard, T.F.; Dagnæs-Hansen, F.; Meldgaard, P.; Sorensen, B.S.; Nielsen, A.L. Up-Regulated FGFR1 Expression as a Mediator of Intrinsic TKI Resistance in EGFR-Mutated NSCLC. Transl. Oncol. 2019, 12, 432-440. [CrossRef]

46. Boichuk, S.; Galembikova, A.; Dunaev, P.; Valeeva, E.; Shagimardanova, E.; Gusev, O.; Khaiboullina, S. A novel receptor tyrosine kinase switch promotes gastrointestinal stromal tumor drug resistance. Molecules 2017, 22, 2152. [CrossRef]

47. Yadav, V.; Zhang, X.; Liu, J.; Estrem, S.; Li, S.; Gong, X.Q.; Buchanan, S.; Henry, J.R.; Starling, J.J.; Peng, S. Bin Reactivation of Mitogen-activated Protein Kinase (MAPK) pathway by FGF Receptor 3 (FGFR3)/Ras mediates resistance to vemurafenib in human B-RAF V600E mutant melanoma. J. Biol. Chem. 2012, 287, 28087-28098. [CrossRef]

48. Zhang, L.; Kharbanda, S.; Chen, D.; Bullocks, J.; Miller, D.L.; Ding, I.Y.F.; Hanfelt, J.; McLeskey, S.W.; Kern, F.G. MCF-7 breast carcinoma cells overexpressing FGF-1 form vascularized, metastatic tumors in ovariectomized or tamoxifen-treated nude mice. Oncogene 1997, 15, 2093-2108. [CrossRef] [PubMed]

49. Levine, K.M.; Priedigkeit, N.; Basudan, A.; Tasdemir, N.; Sikora, M.J.; Sokol, E.S.; Hartmaier, R.J.; Ding, K.; Ahmad, N.Z.; Watters, R.J.; et al. FGFR4 overexpression and hotspot mutations in metastatic er+ breast cancer are enriched in the lobular subtype. $n p j$ Breast Cancer 2019, 5, 19. [CrossRef]

50. Sahores, A.; Figueroa, V.; May, M.; Liguori, M.; Rubstein, A.; Fuentes, C.; Jacobsen, B.M.; Elía, A.; Rojas, P.; Sequeira, G.R.; et al. Increased High Molecular Weight FGF2 in Endocrine-Resistant Breast Cancer. Horm. Cancer 2018, 9, 338-348. [CrossRef] [PubMed]

51. Turczyk, L.; Kitowska, K.; Mieszkowska, M.; Mieczkowski, K.; Czaplinska, D.; Piasecka, D.; Kordek, R.; Skladanowski, A.C.; Potemski, P.; Romanska, H.M.; et al. FGFR2-Driven Signaling Counteracts Tamoxifen Effect on ER $\alpha$-Positive Breast Cancer Cells Neoplasia 2017, 19, 791-804. [CrossRef] [PubMed]

52. Turkington, R.C.; Longley, D.B.; Allen, W.L.; Stevenson, L.; McLaughlin, K.; Dunne, P.D.; Blayney, J.K.; Salto-Tellez, M.; Van Schaeybroeck, S.; Johnston, P.G. Fibroblast growth factor receptor 4 (FGFR4): A targetable regulator of drug resistance in colorectal cancer. Cell Death Dis. 2014, 5, e1046. [CrossRef]

53. Gyanchandani, R.; Ortega Alves, M.V.; Myers, J.N.; Kim, S. A proangiogenic signature is revealed in FGF-mediated bevacizumabresistant head and neck squamous cell carcinoma. Mol. Cancer Res. 2013, 11, 1585-1596. [CrossRef] [PubMed]

54. Zhang, D.; Han, L.L.; Du, F.; Liu, X.M.; Li, J.; Wang, H.H.; Song, M.H.; Li, Z.; Li, G.Y. FGFR1 induces acquired resistance against gefitinib by activating AKT/mTOR pathway in NSCLC. Onco Targets Ther. 2019, 12, 9809-9816. [CrossRef]

55. Karajannis, M.A.; Vincent, L.; DiRenzo, R.; Shmelkov, S.V.; Zhang, F.; Feldman, E.J.; Bohlen, P.; Zhu, Z.; Sun, H.; Kussie, P.; et al. Activation of FGFR1 $\beta$ signaling pathway promotes survival, migration and resistance to chemotherapy in acute myeloid leukemia cells. Leukemia 2006, 20, 979-986. [CrossRef] [PubMed]

56. Manousakidi, S.; Guillaume, A.; Pirou, C.; Bouleau, S.; Mignotte, B.; Renaud, F.; Le Floch, N. FGF1 induces resistance to chemotherapy in ovarian granulosa tumor cells through regulation of p53 mitochondrial localization. Oncogenesis 2018, 7, 18. [CrossRef]

57. Kong, S.; Cao, Y.; Li, X.; Li, Z.; Xin, Y.; Meng, Y. MiR-3116 sensitizes glioma cells to temozolomide by targeting FGFR1 and regulating the FGFR1/PI3K/AKT pathway. J. Cell. Mol. Med. 2020, 24, 4677-4686. [CrossRef] [PubMed]

58. Tomé, M.; Tchorz, J.; Gassmann, M.; Bettler, B. Constitutive activation of Notch2 signalling confers chemoresistance to neural stem cells via transactivation of fibroblast growth factor receptor-1. Stem Cell Res. 2019, 35, 101390. [CrossRef]

59. Lee, S.; Rauch, J.; Kolch, W. Targeting MAPK signaling in cancer: Mechanisms of drug resistance and sensitivity. Int. J. Mol. Sci. 2020, 21, 1102. [CrossRef]

60. Chen, Z.; Gibson, T.B.; Robinson, F.; Silvestro, L.; Pearson, G.; Xu, B.E.; Wright, A.; Vanderbilt, C.; Cobb, M.H. MAP kinases. Chem. Rev. 2001, 101, 2449-2476. [CrossRef]

61. Manchado, E.; Weissmueller, S.; Morris, J.P.; Chen, C.C.; Wullenkord, R.; Lujambio, A.; De Stanchina, E.; Poirier, J.T.; Gainor, J.F.; Corcoran, R.B.; et al. A combinatorial strategy for treating KRAS-mutant lung cancer. Nature 2016, 534, 647-651. [CrossRef] [PubMed] 
62. Wang, V.E.; Xue, J.Y.; Frederick, D.T.; Cao, Y.; Lin, E.; Wilson, C.; Urisman, A.; Carbone, D.P.; Flaherty, K.T.; Bernards, R.; et al. Adaptive Resistance to Dual BRAF/MEK Inhibition in BRAF-Driven Tumors through Autocrine FGFR Pathway Activation. Clin. Cancer Res. 2019, 25, 7202-7217. [CrossRef]

63. McLeskey, S.W.; Kurebayashi, J.; Honig, S.F.; Zwiebel, J.; Lippman, M.E.; Dickson, R.B.; Kern, F.G. Fibroblast growth factor 4 transfection of MCF-7 cells produces cell lines that are tumorigenic and metastatic in ovariectomized or tamoxifen-treated athymic nude mice. Cancer Res. 1993, 53, 2168-2177.

64. Shee, K.; Yang, W.; Hinds, J.W.; Hampsch, R.A.; Varn, F.S.; Traphagen, N.A.; Patel, K.; Cheng, C.; Jenkins, N.P.; Kettenbach, A.N.; et al. Therapeutically targeting tumor microenvironment- mediated drug resistance in estrogen receptor-positive breast cancer. $J$. Exp. Med. 2018, 215, 895-910. [CrossRef]

65. Thottassery, J.V.; Sun, Y.; Westbrook, L.; Rentz, S.S.; Manuvakhova, M.; Qu, Z.; Samuel, S.; Upshaw, R.; Cunningham, A.; Kern, F.G. Prolonged extracellular signal-regulated kinase $1 / 2$ activation during fibroblast growth factor 1- of heregulin $\beta 1$-induced antiestrogen-resistant growth of breast cancer cells is resistant to mitogen-activated protein/extracellular regulated kinase kinase. Cancer Res. 2004, 64, 4637-4647. [CrossRef]

66. Turner, N.; Pearson, A.; Sharpe, R.; Lambros, M.; Geyer, F.; Lopez-Garcia, M.A.; Natrajan, R.; Marchio, C.; Iorns, E.; Mackay, A.; et al. FGFR1 amplification drives endocrine therapy resistance and is a therapeutic target in breast cancer. Cancer Res. 2010, 70, 2085-2094. [CrossRef]

67. Tomlinson, D.C.; Knowles, M.A.; Speirs, V. Mechanisms of FGFR3 actions in endocrine resistant breast cancer. Int. J. Cancer 2012, 130, 2857-2866. [CrossRef] [PubMed]

68. Mao, P.; Cohen, O.; Kowalski, K.J.; Kusiel, J.G.; Buendia-Buendia, J.E.; Cuoco, M.S.; Exman, P.; Wander, S.A.; Waks, A.G.; Nayar, U.; et al. Acquired FGFR and FGF Alterations Confer Resistance to Estrogen Receptor (ER) Targeted Therapy in ER + Metastatic Breast Cancer. Clin. Cancer Res. 2020, 26, 5974-5989. [CrossRef] [PubMed]

69. Manuvakhova, M.; Thottassery, J.V.; Hays, S.; Qu, Z.; Rentz, S.S.; Westbrook, L.; Kern, F.G. Expression of the SNT-1/FRS2 phosphotyrosine binding domain inhibits activation of MAP kinase and PI3-kinase pathways and antiestrogen resistant growth induced by FGF-1 in human breast carcinoma cells. Oncogene 2006, 25, 6003-6014. [CrossRef] [PubMed]

70. Brognard, J.; Clark, A.S.; Ni, Y.; Dennis, P.A. Akt/ pbotein kinace B is constitutively active in non-small cell lung cancer cells and promotes cellular survival and resistance to chemotherapy and radiation. Cancer Res. 2001, 61, 3986-3997.

71. Cheng, G.Z.; Chan, J.; Wang, Q.; Zhang, W.; Sun, C.D.; Wang, L.H. Twist transcriptionally up-regulates AKT2 in breast cancer cells leading to increased migration, invasion, and resistance to paclitaxel. Cancer Res. 2007, 67, 1979-1987. [CrossRef]

72. Liu, L.Z.; Zhou, X.D.; Qian, G.; Shi, X.; Fang, J.; Jiang, B.H. AKT1 amplification regulates cisplatin resistance in human lung cancer cells through the mammalian target of rapamycin/p70s6K1 pathway. Cancer Res. 2007, 67, 6325-6332. [CrossRef] [PubMed]

73. Clark, A.S.; West, K.; Streicher, S.; Dennis, P.A. Constitutive and inducible Akt activity promotes resistance to chemotherapy, trastuzumab, or tamoxifen in breast cancer cells. Mol. Cancer Ther. 2002, 1, 707-717.

74. Fujiwara, M.; Izuishi, K.; Sano, T.; Hossain, M.A.; Kimura, S.; Masaki, T.; Suzuki, Y. Modulating effect of the PI3-kinase inhibitor LY294002 on cisplatin in human pancreatic cancer cells. J. Exp. Clin. Cancer Res. 2008, 27, 76. [CrossRef]

75. Shariati, M.; Meric-Bernstam, F. Targeting AKT for cancer therapy. Expert Opin. Investig. Drugs 2019, 28, 977-988. [CrossRef]

76. Xu, W.; Yang, Z.; Lu, N. A new role for the PI3K/Akt signaling pathway in the epithelial-mesenchymal transition. Cell Adhes. Migr. 2015, 9, 317-324. [CrossRef]

77. Hu, Y.; Lu, H.; Zhang, J.; Chen, J.; Chai, Z.; Zhang, J. Essential role of AKT in tumor cells addicted to FGFR. Anticancer Drugs 2014, 25, 183-188. [CrossRef]

78. Sun, B.; Xu, H.; Zhang, G.; Zhu, Y.; Sun, H.; Hou, G. Basic fibroblast growth factor upregulates survivin expression in hepatocellular carcinoma cells via a protein kinase B-dependent pathway. Oncol. Rep. 2013, 30, 385-390. [CrossRef] [PubMed]

79. Tran, J.; Master, Z.; Yu, J.L.; Rak, J.; Dumont, D.J.; Kerbel, R.S. A role for survivin in chemoresistance of endothelial cells mediated by VEGF. Proc. Natl. Acad. Sci. USA 2002, 99, 4349-4354. [CrossRef] [PubMed]

80. Kono, S.A.; Marshall, M.E.; Ware, K.E.; Heasley, L.E. The fibroblast growth factor receptor signaling pathway as a mediator of intrinsic resistance to EGFR-specific tyrosine kinase inhibitors in non-small cell lung cancer. Drug Resist. Updates 2009, 12, 95-102. [CrossRef]

81. Kurimoto, R.; Iwasawa, S.; Ebata, T.; Ishiwata, T.; Sekine, I.; Tada, Y.; Tatsumi, K.; Koide, S.; Iwama, A.; Takiguchi, Y. Drug resistance originating from a TGF- $\beta$ /FGF-2-driven epithelial-to-mesenchymal transition and its reversion in human lung adenocarcinoma cell lines harboring an EGFR mutation. Int. J. Oncol. 2016, 48, 1825-1836. [CrossRef]

82. Ware, K.E.; Hinz, T.K.; Kleczko, E.; Singleton, K.R.; Marek, L.A.; Helfrich, B.A.; Cummings, C.T.; Graham, D.K.; Astling, D.; Tan, A.C.; et al. A mechanism of resistance to gefitinib mediated by cellular reprogramming and the acquisition of an FGF2-FGFR1 autocrine growth loop. Oncogenesis 2013, 2, e39. [CrossRef]

83. Terai, H.; Soejima, K.; Yasuda, H.; Nakayama, S.; Hamamoto, J.; Arai, D.; Ishioka, K.; Ohgino, K.; Ikemura, S.; Sato, T.; et al. Activation of the FGF2-FGFR1 autocrine pathway: A novel mechanism of acquired resistance to gefitinib in NSCLC. Mol. Cancer Res. 2013, 11, 759-767. [CrossRef]

84. Kim, H.R.; Heo, Y.M.; Jeong, K.I.; Kim, Y.M.; Jang, H.L.; Lee, K.Y.; Yeo, C.Y.; Kim, S.H.; Lee, H.K.; Kim, S.R.; et al. FGF-2 inhibits TNF- $\alpha$ mediated apoptosis through upregulation of Bcl2-A1 and Bcl-xL in ATDC5 cells. BMB Rep. 2012, 45, 287-292. [CrossRef]

85. Teng, Y.; Zhao, H.; Gao, L.; Zhang, W.; Shull, A.Y.; Shay, C. FGF19 protects hepatocellular carcinoma cells against endoplasmic reticulum stress via activation of FGFR4-GSK3 $\beta-N r f 2$ signaling. Cancer Res. 2017, 77, 6215-6225. [CrossRef] [PubMed] 
86. Metzner, T.; Bedeir, A.; Held, G.; Peter-Vörösmarty, B.; Ghassemi, S.; Heinzle, C.; Spiegl-Kreinecker, S.; Marian, B.; Holzmann, K.; Grasl-Kraupp, B.; et al. Fibroblast growth factor receptors as therapeutic targets in human melanoma: Synergism with BRAF inhibition. J. Investig. Dermatol. 2011, 131, 2087-2095. [CrossRef]

87. Grimm, J.; Hufnagel, A.; Wobser, M.; Borst, A.; Haferkamp, S.; Houben, R.; Meierjohann, S. BRAF inhibition causes resilience of melanoma cell lines by inducing the secretion of FGF1. Oncogenesis 2018, 7, 71. [CrossRef] [PubMed]

88. Bhola, N.E.; Jansen, V.M.; Koch, J.P.; Li, H.; Formisano, L.; Williams, J.A.; Grandis, J.R.; Arteaga, C.L. Treatment of triple-negative breast cancer with TORC1/2 inhibitors sustains a drug-resistant and notch-dependent cancer stem cell population. Cancer Res. 2016, 76, 440-452. [CrossRef] [PubMed]

89. Mori, M.; Mori, T.; Yamamoto, A.; Takagi, S.; Ueda, M. Proliferation of poorly differentiated endometrial cancer cells through autocrine activation of FGF receptor and HES1 expression. Hum. Cell 2019, 32, 367-378. [CrossRef]

90. Liu, Z.H.; Dai, X.M.; Du, B. Hes1: A key role in stemness, metastasis and multidrug resistance. Cancer Biol. Ther. 2015, 16, 353-359. [CrossRef]

91. Zhou, W.; Su, Y.; Zhang, Y.; Han, B.; Liu, H.; Wang, X. Endothelial Cells Promote Docetaxel Resistance of Prostate Cancer Cells by Inducing ERG Expression and Activating Akt/mTOR Signaling Pathway. Front. Oncol. 2020, 10, 584505. [CrossRef]

92. Huang, S.; Liang, S.; Chen, G.; Chen, J.; You, K.; Ye, H.; Li, Z.; He, S. Overexpression of glycosyltransferase 8 domain containing 2 confers ovarian cancer to CDDP resistance by activating FGFR/PI3K signalling axis. Oncogenesis 2021, 10, 55. [CrossRef]

93. Pan, X.; Zhou, T.; Tai, Y.H.; Wang, C.; Zhao, J.; Cao, Y.; Chen, Y.; Zhang, P.J.; Yu, M.; Zhen, C.; et al. Elevated expression of CUEDC2 protein confers endocrine resistance in breast cancer. Nat. Med. 2011, 17, 708-714. [CrossRef]

94. Owen, K.L.; Brockwell, N.K.; Parker, B.S. Jak-stat signaling: A double-edged sword of immune regulation and cancer progression. Cancers 2019, 11, 2002. [CrossRef]

95. Song, L.; Turkson, J.; Karras, J.G.; Jove, R.; Haura, E.B. Activation of Stat3 by receptor tyrosine kinases and cytokines regulates survival in human non-small cell carcinoma cells. Oncogene 2003, 22, 4150-4165. [CrossRef] [PubMed]

96. Bohrer, L.R.; Chuntova, P.; Bade, L.K.; Beadnell, T.C.; Leon, R.P.; Brady, N.J.; Ryu, Y.; Goldberg, J.E.; Schmechel, S.C.; Koopmeiners, J.S.; et al. Activation of the FGFR-STAT3 pathway in breast cancer cells induces a hyaluronan-rich microenvironment that licenses tumor formation. Cancer Res. 2014, 74, 374-386. [CrossRef]

97. Plowright, E.E.; Li, Z.; Bergsagel, P.L.; Chesi, M.; Barber, D.L.; Branch, D.R.; Hawley, R.G.; Stewart, A.K. Ectopic expression of fibroblast growth factor receptor 3 promotes myeloma cell proliferation and prevents apoptosis. Blood 2000, 95, 992-998. [CrossRef]

98. Li, P.; Huang, T.; Zou, Q.; Liu, D.; Wang, Y.; Tan, X.; Wei, Y.; Qiu, H. FGFR2 Promotes Expression of PD-L1 in Colorectal Cancer via the JAK/STAT3 Signaling Pathway. J. Immunol. 2019, 202, 3065-3075. [CrossRef] [PubMed]

99. Song, X.; Tang, W.; Peng, H.; Qi, X.; Li, J. FGFR leads to sustained activation of STAT3 to mediate resistance to EGFR-TKIs treatment. Investig. New Drugs 2021, 39, 1201-1212. [CrossRef] [PubMed]

100. Carmo, C.R.; Lyons-Lewis, J.; Seckl, M.J.; Costa-Pereira, A.P. A novel requirement for Janus Kinases as mediators of drug resistance induced by fibroblast growth factor-2 in human cancer cells. PLoS ONE 2011, 6, e19861. [CrossRef] [PubMed]

101. Jang, H.J.; Suh, P.G.; Lee, Y.J.; Shin, K.J.; Cocco, L.; Chae, Y.C. PLC $\gamma 1$ : Potential arbitrator of cancer progression. Adv. Biol. Regul. 2018, 67, 179-189. [CrossRef] [PubMed]

102. Pardo, O.E.; Wellbrock, C.; Khanzada, U.K.; Aubert, M.; Arozarena, I.; Davidson, S.; Bowen, F.; Parker, P.J.; Filonenko, V.V.; Gout, I.T.; et al. FGF-2 protects small cell lung cancer cells from apoptosis through a complex involving PKCE, B-Raf and S6K2. EMBO J. 2006, 25, 3078-3088. [CrossRef] [PubMed]

103. Tomlinson, D.C.; Lamont, F.R.; Shnyder, S.D.; Knowles, M.A. Fibroblast growth factor receptor 1 promotes proliferation and survival via activation of the mitogen-activated protein kinase pathway in bladder cancer. Cancer Res. 2009, 69, 4613-4620. [CrossRef] [PubMed]

104. Kuzet, S.E.; Gaggioli, C. Fibroblast activation in cancer: When seed fertilizes soil. Cell Tissue Res. 2016, 365, 607-619. [CrossRef] [PubMed]

105. Santolla, M.F.; Maggiolini, M. The FGF/FGFR System in Breast Cancer: Oncogenic Features and Therapeutic Perspectives. Cancers 2020, 12, 3029. [CrossRef]

106. Zhang, X.; Nie, D.; Chakrabarty, S. Growth factors in tumor microenvironment. Front. Biosci. 2010, 15, 151-165. [CrossRef]

107. Katoh, M. FGFR inhibitors: Effects on cancer cells, tumor microenvironment and whole-body homeostasis (Review). Int. J. Mol. Med. 2016, 38, 3-15. [CrossRef]

108. Giulianelli, S.; Cerliani, J.P.; Lamb, C.A.; Fabris, V.T.; Bottino, M.C.; Gorostiaga, M.A.; Novaro, V.; Góngora, A.; Baldi, A.; Molinolo, A.; et al. Carcinoma-associated fibroblasts activate progesterone receptors and induce hormone independent mammary tumor growth: A role for the FGF-2/FGFR-2 axis. Int. J. Cancer 2008, 123, 2518-2531. [CrossRef]

109. Hegab, A.E.; Ozaki, M.; Kameyama, N.; Gao, J.; Kagawa, S.; Yasuda, H.; Soejima, K.; Yin, Y.; Guzy, R.D.; Nakamura, Y.; et al. Effect of FGF/FGFR pathway blocking on lung adenocarcinoma and its cancer-associated fibroblasts. J. Pathol. 2019, 249, 193-205. [CrossRef]

110. Kumar, D.; New, J.; Vishwakarma, V.; Joshi, R.; Enders, J.; Lin, F.; Dasari, S.; Gutierrez, W.R.; Leef, G.; Ponnurangam, S.; et al. Cancer-Associated Fibroblasts Drive Glycolysis in a Targetable Signaling Loop Implicated in Head and Neck Squamous Cell Carcinoma Progression. Cancer Res. 2018, 78, 3769-3782. [CrossRef] 
111. Awaji, M.; Futakuchi, M.; Heavican, T.; Iqbal, J.; Singh, R.K. Cancer-Associated Fibroblasts Enhance Survival and Progression of the Aggressive Pancreatic Tumor via FGF-2 and CXCL8. Cancer Microenviron. 2019, 12, 37-46. [CrossRef]

112. Fernández-Nogueira, P.; Mancino, M.; Fuster, G.; López-Plana, A.; Jauregui, P.; Almendro, V.; Enreig, E.; Menéndez, S.; Rojo, F.; Noguera-Castells, A.; et al. Tumor-associated fibroblasts promote HER2-targeted therapy resistance through FGFR2 activation. Clin. Cancer Res. 2020, 26, 1432-1448. [CrossRef] [PubMed]

113. Suh, J.; Kim, D.H.; Lee, Y.H.; Jang, J.H.; Surh, Y.J. Fibroblast growth factor-2, derived from cancer-associated fibroblasts, stimulates growth and progression of human breast cancer cells via FGFR1 signaling. Mol. Carcinog. 2020, 59, 1028-1040. [CrossRef] [PubMed]

114. Sakata, K.; Kato, S.; Fox, J.C.; Shigemori, M.; Morimatsu, M. Autocrine signaling through ras regulates cell survival activity in human glioma cells: Potential cross-talk between ras and the phosphatidylinositol 3-kinase-akt pathway. J. Neuropathol. Exp. Neurol. 2002, 61, 975-983. [CrossRef]

115. Shimizu, T.; Tolcher, A.W.; Papadopoulos, K.P.; Beeram, M.; Rasco, D.W.; Smith, L.S.; Gunn, S.; Smetzer, L.; Mays, T.A.; Kaiser, B.; et al. The clinical effect of the dual-targeting strategy involving PI3K/AKT/mTOR and RAS/MEK/ERK pathways in patients with advanced cancer. Clin. Cancer Res. 2012, 18, 2316-2325. [CrossRef] [PubMed]

116. Lee, E.R.; Kim, J.Y.; Kang, Y.J.; Ahn, J.Y.; Kim, J.H.; Kim, B.W.; Choi, H.Y.; Jeong, M.Y.; Cho, S.G. Interplay between PI3K/Akt and MAPK signaling pathways in DNA-damaging drug-induced apoptosis. Biochim. Biophys. Acta Mol. Cell Res. 2006, 1763, 958-968. [CrossRef]

117. Wee, S.; Jagani, Z.; Kay, X.X.; Loo, A.; Dorsch, M.; Yao, Y.M.; Sellers, W.R.; Lengauer, C.; Stegmeier, F. PI3K pathway activation mediates resistance to MEK inhibitors in KRAS mutant cancers. Cancer Res. 2009, 69, 4286-4293. [CrossRef]

118. Ban, M.J.; Byeon, H.K.; Yang, Y.J.; An, S.; Kim, J.W.; Kim, J.H.; Kim, D.H.; Yang, J.; Kee, H.; Koh, Y.W. Fibroblast growth factor receptor 3-mediated reactivation of ERK signaling promotes head and neck squamous cancer cell insensitivity to MEK inhibition. Cancer Sci. 2018, 109, 3816-3825. [CrossRef]

119. Pardo, O.E.; Arcaro, A.; Salerno, G.; Tetley, T.D.; Valovka, T.; Gout, I.; Seckl, M.J. Novel cross talk between MEK and S6K2 in FGF-2 induced proliferation of SCLC cells. Oncogene 2001, 20, 7658-7667. [CrossRef] [PubMed]

120. Binju, M.; Amaya-Padilla, M.A.; Wan, G.; Gunosewoyo, H.; Rahmanto, Y.S.; Yu, Y. Therapeutic inducers of apoptosis in ovarian cancer. Cancers 2019, 11, 1786. [CrossRef]

121. Pardo, O.E.; Arcaro, A.; Salerno, G.; Raguz, S.; Downward, J.; Seckl, M.J. Fibroblast growth factor-2 induces translational regulation of $\mathrm{Bcl}-\mathrm{XL}$ and $\mathrm{Bcl}-2$ via a MEK-dependent pathway: Correlation with resistance to etoposide-induced apoptosis. J. Biol. Chem. 2002, 277, 12040-12046. [CrossRef] [PubMed]

122. Pardo, O.E.; Lesay, A.; Arcaro, A.; Lopes, R.; Ng, B.L.; Warne, P.H.; McNeish, I.A.; Tetley, T.D.; Lemoine, N.R.; Mehmet, H.; et al. Fibroblast Growth Factor 2-Mediated Translational Control of IAPs Blocks Mitochondrial Release of Smac/DIABLO and Apoptosis in Small Cell Lung Cancer Cells. Mol. Cell. Biol. 2003, 24, 6887. [CrossRef]

123. Shaulian, E.; Resnitzky, D.; Shifman, O.; Blandino, G.; Amsterdam, A.; Yayon, A.; Oren, M. Induction of Mdm2 and enhancement of cell survival by bFGF. Oncogene 1997, 15, 2717-2725. [CrossRef]

124. Bouleau, S.; Grimal, H.; Rincheval, V.; Godefroy, N.; Mignotte, B.; Vayssière, J.L.; Renaud, F. FGF1 inhibits p53-dependent apoptosis and cell cycle arrest via an intracrine pathway. Oncogene 2005, 24, 7839-7849. [CrossRef]

125. Jung, C.R.; Lim, J.H.; Choi, Y.; Kim, D.G.; Kang, K.J.; Noh, S.M.; Im, D.S. Enigma negatively regulates p53 through MDM2 and promotes tumor cell survival in mice. J. Clin. Investig. 2010, 120, 4493-4506. [CrossRef] [PubMed]

126. Zakrzewska, M.; Sørensen, V.; Jin, Y.; Wiedlocha, A.; Olsnes, S. Translocation of exogenous FGF1 into cytosol and nucleus is a periodic event independent of receptor kinase activity. Exp. Cell Res. 2011, 317, 1005-1015. [CrossRef]

127. Kostas, M.; Lampart, A.; Bober, J.; Wiedlocha, A.; Tomala, J.; Krowarsch, D.; Otlewski, J.; Zakrzewska, M. Translocation of Exogenous FGF1 and FGF2 Protects the Cell against Apoptosis Independently of Receptor Activation. J. Mol. Biol. 2018, 430, 4087-4101. [CrossRef]

128. Sluzalska, K.D.; Slawski, J.; Sochacka, M.; Lampart, A.; Otlewski, J.; Zakrzewska, M. Intracellular partners of fibroblast growth factors 1 and 2-Implications for functions. Cytokine Growth Factor Rev. 2020, 57, 93-111. [CrossRef]

129. Rodriguez-Enfedaque, A.; Bouleau, S.; Laurent, M.; Courtois, Y.; Mignotte, B.; Vayssière, J.L.; Renaud, F. FGF1 nuclear translocation is required for both its neurotrophic activity and its p53-dependent apoptosis protection. Biochim. Biophys. Acta Mol. Cell Res. 2009, 1793, 1719-1727. [CrossRef]

130. Li, S.; Payne, S.; Wang, F.; Claus, P.; Su, Z.; Groth, J.; Geradts, J.; de Ridder, G.; Alvarez, R.; Marcom, P.K.; et al. Nuclear basic fibroblast growth factor regulates triple-negative breast cancer chemo-resistance. Breast Cancer Res. 2015, 17, 91. [CrossRef]

131. Grose, R.; Fantl, V.; Werner, S.; Chioni, A.M.; Jarosz, M.; Rudling, R.; Cross, B.; Hart, I.R.; Dickson, C. The role of fibroblast growth factor receptor $2 \mathrm{~b}$ in skin homeostasis and cancer development. EMBO J. 2007, 26, 1268-1278. [CrossRef]

132. Chioni, A.M.; Grose, R. FGFR1 cleavage and nuclear translocation regulates breast cancer cell behavior. J. Cell Biol. 2012, 197, 801-817. [CrossRef] [PubMed]

133. Coleman, S.J.; Chioni, A.M.; Ghallab, M.; Anderson, R.K.; Lemoine, N.R.; Kocher, H.M.; Grose, R.P. Nuclear translocation of FGFR1 and FGF2 in pancreatic stellate cells facilitates pancreatic cancer cell invasion. EMBO Mol. Med. 2014, 6, 467-481. [CrossRef] [PubMed]

134. Li, C.; Iida, M.; Dunn, E.F.; Ghia, A.J.; Wheeler, D.L. Nuclear EGFR contributes to acquired resistance to cetuximab. Oncogene 2009, 28, 3801-3813. [CrossRef] [PubMed] 
135. Formisano, L.; Stauffer, K.M.; Young, C.D.; Bhola, N.E.; Guerrero-Zotano, A.L.; Jansen, V.M.; Estrada, M.M.; Hutchinson, K.E.; Giltnane, J.M.; Schwarz, L.J.; et al. Association of FGFR1 with ER $\alpha$ maintains ligand-independent ER transcription and mediates resistance to estrogen deprivation in ER+ breast cancer. Clin. Cancer Res. 2017, 23, 6138-6151. [CrossRef]

136. Roidl, A.; Berger, H.J.; Kumar, S.; Bange, J.; Knyazev, P.; Ullrich, A. Resistance to chemotherapy is associated with fibroblast growth factor receptor 4 up-regulation. Clin. Cancer Res. 2009, 15, 2058-2066. [CrossRef] [PubMed]

137. Young, R.J.; Fernando, M.; Hughes, D.; Brown, N.J.; Woll, P.J. Angiogenic growth factor expression in benign and malignant vascular tumours. Exp. Mol. Pathol. 2014, 97, 148-153. [CrossRef]

138. Conconi, M.T.; Nico, B.; Guidolin, D.; Baiguera, S.; Spinazzi, R.; Rebuffat, P.; Malendowicz, L.K.; Vacca, A.; Carraro, G.; Parnigotto, P.P.; et al. Ghrelin inhibits FGF-2-mediated angiogenesis in vitro and in vivo. Peptides 2004, 25, 2179-2185. [CrossRef]

139. Herbert, S.P.; Stainier, D.Y.R. Molecular control of endothelial cell behaviour during blood vessel morphogenesis. Nat. Rev. Mol. Cell Biol. 2011, 12, 551-564. [CrossRef]

140. Inoue, K.; Slaton, J.W.; Karashima, T.; Yoshikawa, C.; Shuin, T.; Sweeney, P.; Millikan, R.; Dinney, C.P.N. The prognostic value of angiogenesis factor expression for predicting recurrence and metastasis of bladder cancer after neoadjuvant chemotherapy and radical cystectomy. Clin. Cancer Res. 2000, 6, 4866-4873.

141. Ucuzian, A.A.; Gassman, A.A.; East, A.T.; Greisler, H.P. Molecular mediators of angiogenesis. J. Burn Care Res. 2010, 31, 158-175. [CrossRef]

142. Huang, X.; Yu, C.; Jin, C.; Kobayashi, M.; Bowles, C.A.; Wang, F.; McKeehan, W.L. Ectopic activity of fibroblast growth factor receptor 1 in hepatocytes accelerates hepatocarcinogenesis by driving proliferation and vascular endothelial growth factor-induced angiogenesis. Cancer Res. 2006, 66, 1481-1490. [CrossRef]

143. Presta, M.; Dell'Era, P.; Mitola, S.; Moroni, E.; Ronca, R.; Rusnati, M. Fibroblast growth factor/fibroblast growth factor receptor system in angiogenesis. Cytokine Growth Factor Rev. 2005, 16, 159-178. [CrossRef]

144. Schönau, K.K.; Steger, G.G.; Mader, R.M. Angiogenic effect of naive and 5-fluorouracil resistant colon carcinoma on endothelial cells in vitro. Cancer Lett. 2007, 257, 73-78. [CrossRef]

145. Porta, C.; Paglino, C.; Imarisio, I.; Ganini, C.; Sacchi, L.; Quaglini, S.; Giunta, V.; De Amici, M. Changes in circulating proangiogenic cytokines, other than VEGF, before progression to sunitinib therapy in advanced renal cell carcinoma patients. Oncology 2012, 84, 115-122. [CrossRef]

146. Guerrin, M.; Scotet, E.; Malecaze, F.; Houssaint, E.; Plouët, J. Overexpression of vascular endothelial growth factor induces cell transformation in cooperation with fibroblast growth factor 2. Oncogene 1997, 14, 463-471. [CrossRef]

147. Yoshiji, H.; Kuriyama, S.; Yoshii, J.; Ikenaka, Y.; Noguchi, R.; Hicklin, D.J.; Huber, J.; Nakatani, T.; Tsujinoue, H.; Yanase, K.; et al. Synergistic effect of basic fibroblast growth factor and vascular endothelial growth factor in murine hepatocellular carcinoma. Hepatology 2002, 35, 834-842. [CrossRef] [PubMed]

148. Ichikawa, K.; Watanabe Miyano, S.; Minoshima, Y.; Matsui, J.; Funahashi, Y. Activated FGF2 signaling pathway in tumor vasculature is essential for acquired resistance to anti-VEGF therapy. Sci. Rep. 2020, 10, 2939. [CrossRef] [PubMed]

149. Vitale, D.L.; Spinelli, F.M.; Del Dago, D.; Icardi, A.; Demarchi, G.; Caon, I.; García, M.; Bolontrade, M.F.; Passi, A.; Cristina, C.; et al. Co-treatment of tumor cells with hyaluronan plus doxorubicin affects endothelial cell behavior independently of VEGF expression. Oncotarget 2018, 9, 36585-36602. [CrossRef]

150. Casanovas, O.; Hicklin, D.J.; Bergers, G.; Hanahan, D. Drug resistance by evasion of antiangiogenic targeting of VEGF signaling in late-stage pancreatic islet tumors. Cancer Cell 2005, 8, 299-309. [CrossRef] [PubMed]

151. Park, J.Y.; Kim, P.J.; Shin, S.J.; Lee, J.L.; Cho, Y.M.; Go, H. FGFR1 is associated with c-MYC and proangiogenic molecules in metastatic renal cell carcinoma under anti-angiogenic therapy. Histopathology 2020, 76, 838-851. [CrossRef] [PubMed]

152. Giacomini, A.; Taranto, S.; Rezzola, S.; Matarazzo, S.; Grillo, E.; Bugatti, M.; Scotuzzi, A.; Guerra, J.; Trani, M.D.; Presta, M.; et al. Inhibition of the fgf/fgfr system induces apoptosis in lung cancer cells via c-myc downregulation and oxidative stress. Int. J. Mol. Sci. 2020, 21, 9376. [CrossRef]

153. Kikuchi, A.; Suzuki, T.; Nakazawa, T.; Iizuka, M.; Nakayama, A.; Ozawa, T.; Kameda, M.; Shindoh, N.; Terasaka, T.; Hirano, M.; et al. ASP5878, a selective FGFR inhibitor, to treat FGFR3-dependent urothelial cancer with or without chemoresistance. Cancer Sci. 2017, 108, 236-242. [CrossRef] [PubMed]

154. Malchers, F.; Dietlein, F.; Schöttle, J.; Lu, X.; Nogova, L.; Albus, K.; Fernandez-Cuesta, L.; Heuckmann, J.M.; Gautschi, O.; Diebold, J.; et al. Cell-autonomous and non-cell-autonomous mechanisms of transformation by amplified FGFR1 in lung cancer. Cancer Discov. 2014, 4, 246-257. [CrossRef]

155. Chaffer, C.L.; Weinberg, R.A. A Perspective on Cancer Cell Metastasis. Science 2011, 331, 1559-1564. [CrossRef]

156. Singh, M.; Yelle, N.; Venugopal, C.; Singh, S.K. EMT: Mechanisms and therapeutic implications. Pharmacol. Ther. 2018, 182, 80-94. [CrossRef]

157. Kurimoto, R.; Ebata, T.; Iwasawa, S.; Ishiwata, T.; Tada, Y.; Tatsumi, K.; Takiguchi, Y. Pirfenidone may revert the epithelial-tomesenchymal transition in human lung adenocarcinoma. Oncol. Lett. 2017, 14, 944-950. [CrossRef]

158. Suyama, K.; Shapiro, I.; Guttman, M.; Hazan, R.B. A signaling pathway leading to metastasis is controlled by N-cadherin and the FGF receptor. Cancer Cell 2002, 2, 301-314. [CrossRef]

159. Wheelock, M.J.; Shintani, Y.; Maeda, M.; Fukumoto, Y.; Johnson, K.R. Cadherin switching. J. Cell Sci. 2008, 121, 727-735. [CrossRef] 
160. Nguyen, P.T.; Tsunematsu, T.; Yanagisawa, S.; Kudo, Y.; Miyauchi, M.; Kamata, N.; Takata, T. The FGFR1 inhibitor PD173074 induces mesenchymal-epithelial transition through the transcription factor AP-1. Br. J. Cancer 2013, 109, 2248-2258. [CrossRef] [PubMed]

161. Nguyen, T.; Mège, R.M. N-Cadherin and Fibroblast Growth Factor Receptors crosstalk in the control of developmental and cancer cell migrations. Eur. J. Cell Biol. 2016, 95, 415-426. [CrossRef] [PubMed]

162. Wang, K.; Ji, W.; Yu, Y.; Li, Z.; Niu, X.; Xia, W.; Lu, S. FGFR1-ERK1/2-SOX2 axis promotes cell proliferation, epithelialmesenchymal transition, and metastasis in FGFR1-amplified lung cancer. Oncogene 2018, 37, 5340-5354. [CrossRef] [PubMed]

163. Chen, J.; Ge, X.; Zhang, W.; Ding, P.; Du, Y.; Wang, Q.; Li, L.; Fang, L.; Sun, Y.; Zhang, P.; et al. PI3K/AKT inhibition reverses R-CHOP resistance by destabilizing SOX2 in diffuse large B cell lymphoma. Theranostics 2020, 10, 3151-3163. [CrossRef] [PubMed]

164. Kornmann, M.; Ishiwata, T.; Matsuda, K.; Lopez, M.E.; Fukahi, K.; Asano, G.; Beger, H.G.; Korc, M. IIIc isoform of fibroblast growth factor receptor 1 is overexpressed in human pancreatic cancer and enhances tumorigenicity of hamster ductal cells. Gastroenterology 2002, 123, 301-313. [CrossRef] [PubMed]

165. Chaffer, C.L.; Brennan, J.P.; Slavin, J.L.; Blick, T.; Thompson, E.W.; Williams, E.D. Mesenchymal-to-epithelial transition facilitates bladder cancer metastasis: Role of fibroblast growth factor receptor-2. Cancer Res. 2006, 66, 11271-11278. [CrossRef] [PubMed]

166. Ranieri, D.; Rosato, B.; Nanni, M.; Magenta, A.; Belleudi, F.; Torrisi, M.R. Expression of the FGFR2 mesenchymal splicing variant in epithelial cells drives epithelial-mesenchymal transition. Oncotarget 2016, 7, 5440-5460. [CrossRef]

167. Ishiwata, T. Role of fibroblast growth factor receptor-2 splicing in normal and cancer cells. Front. Biosci. Landmark 2018, 23, 626-639. [CrossRef] [PubMed]

168. Li, Q.; Ingram, L.; Kim, S.; Beharry, Z.; Cooper, J.A.; Cai, H. Paracrine Fibroblast Growth Factor Initiates Oncogenic Synergy with Epithelial FGFR/Src Transformation in Prostate Tumor Progression. Neoplasia 2018, 20, 233-243. [CrossRef]

169. Hopkins, A.; Coatham, M.L.; Berry, F.B. FOXC1 regulates FGFR1 isoform switching to promote invasion following TGF $\beta$-induced EMT. Mol. Cancer Res. 2017, 15, 1341-1353. [CrossRef]

170. Shoji, K.; Teishima, J.; Hayashi, T.; Ohara, S.; McKeehan, W.L.; Matsubara, A. Restoration of fibroblast growth factor receptor 2IIIb enhances the chemosensitivity of human prostate cancer cells. Oncol. Rep. 2014, 32, 65-70. [CrossRef]

171. Arumugam, T.; Ramachandran, V.; Fournier, K.F.; Wang, H.; Marquis, L.; Abbruzzese, J.L.; Gallick, G.E.; Logsdon, C.D.; McConkey, D.J.; Choi, W. Epithelial to mesenchymal transition contributes to drug resistance in pancreatic cancer. Cancer Res. 2009, 69, 5820-5828. [CrossRef]

172. Li, Q.Q.; Xu, J.D.; Wang, W.J.; Cao, X.X.; Chen, Q.; Tang, F.; Chen, Z.Q.; Liu, X.P.; Xu, Z. De Twist1-mediated adriamycin-induced epithelial-mesenchymal transition relates to multidrug resistance and invasive potential in breast cancer cells. Clin. Cancer Res. 2009, 15, 2657-2665. [CrossRef] [PubMed]

173. Jakobsen, K.R.; Demuth, C.; Madsen, A.T.; Hussmann, D.; Vad-Nielsen, J.; Nielsen, A.L.; Sorensen, B.S. MET amplification and epithelial-to-mesenchymal transition exist as parallel resistance mechanisms in erlotinib-resistant, EGFR-mutated, NSCLC HCC827 cells. Oncogenesis 2017, 6, e307. [CrossRef]

174. Azuma, K.; Kawahara, A.; Sonoda, K.; Nakashima, K.; Tashiro, K.; Watari, K.; Izumi, H.; Kage, M.; Kuwano, M.; Ono, M.; et al. FGFR1 activation is an escape mechanism in human lung cancer cells resistant to afatinib, a pan-EGFR family kinase inhibitor. Oncotarget 2014, 5, 5908-5919. [CrossRef] [PubMed]

175. Abdullah, A.; Akhand, S.S.; Paez, J.S.P.; Brown, W.; Pan, L.; Libring, S.; Badamy, M.; Dykuizen, E.; Solorio, L.; Andy Tao, W.; et al. Epigenetic targeting of neuropilin-1 prevents bypass signaling in drug-resistant breast cancer. Oncogene 2021, 40, 322-333. [CrossRef]

176. Miura, K.; Oba, T.; Hamanaka, K.; Ito, K. ichi FGF2-FGFR1 pathway activation together with thymidylate synthase upregulation is induced in pemetrexed-resistant lung cancer cells. Oncotarget 2019, 10, 1171-1192. [CrossRef] [PubMed]

177. Brown, W.S.; Akhand, S.S.; Wendt, M.K. FGFR signaling maintains a drug persistent cell population following epithelialmesenchymal transition. Oncotarget 2016, 7, 83424-83436. [CrossRef]

178. Koinis, F.; Corn, P.; Parikh, N.; Song, J.; Vardaki, I.; Mourkioti, I.; Lin, S.H.; Logothetis, C.; Panaretakis, T.; Gallick, G. Resistance to MET/VEGFR2 inhibition by cabozantinib is mediated by YAP/TBX5-dependent induction of FGFR1 in castration-resistant prostate cancer. Cancers 2020, 12, 244. [CrossRef]

179. Spinola, M.; Leoni, V.P.; Tanuma, J.I.; Pettinicchio, A.; Frattini, M.; Signoroni, S.; Agresti, R.; Giovanazzi, R.; Pilotti, S.; Bertario, L.; et al. FGFR4 Gly388Arg polymorphism and prognosis of breast and colorectal cancer. Oncol. Rep. 2005, 14, 415-419. [CrossRef]

180. Marmé, F.; Werft, W.; Benner, A.; Burwinkel, B.; Sinn, P.; Sohn, C.; Lichter, P.; Hahn, M.; Schneeweiss, A. FGFR4 Arg388 genotype is associated with pathological complete response to neoadjuvant chemotherapy for primary breast cancer. Ann. Oncol. 2010, 21, 1636-1642. [CrossRef]

181. Thussbas, C.; Nahrig, J.; Streit, S.; Bange, J.; Kriner, M.; Kates, R.; Ulm, K.; Kiechle, M.; Hoefler, H.; Ullrich, A.; et al. FGFR4 Arg388 allele is associated with resistance to adjuvant therapy in primary breast cancer. J. Clin. Oncol. 2006, 24, 3747-3755. [CrossRef] [PubMed]

182. Cho, S.H.; Hong, C.S.; Kim, H.N.; Shin, M.H.; Kim, K.R.; Shim, H.J.; Hwang, J.E.; Bae, W.K.; Chung, I.J. FGFR4 Arg388 is correlated with poor survival in resected colon cancer promoting epithelial to mesenchymal transition. Cancer Res. Treat. 2017, 49, 766-777. [CrossRef] 
183. Ye, Y.; Li, J.; Jiang, D.; Li, J.; Xiao, C.; Li, Y.; Han, C.; Zhao, C. FGFR4 Gly388Arg polymorphism affects the progression of gastric cancer by activating STAT3 pathway to induce epithelial to mesenchymal transition. Cancer Res. Treat. 2020, 52, 1162-1177. [CrossRef] [PubMed]

184. Ansell, A.; Farnebo, L.; Grénman, R.; Roberg, K.; Thunell, L.K. Polymorphism of FGFR4 in cancer development and sensitivity to cisplatin and radiation in head and neck cancer. Oral Oncol. 2009, 45, 23-29. [CrossRef]

185. Marmé, F.; Hielscher, T.; Hug, S.; Bondong, S.; Zeillinger, R.; Castillo-Tong, D.C.; Sehouli, J.; Braicu, I.; Vergote, I.; Isabella, C.; et al. Fibroblast growth factor receptor 4 gene (FGFR4) 388Arg allele predicts prolonged survival and platinum sensitivity in advanced ovarian cancer. Int. J. Cancer 2012, 131, 586-591. [CrossRef] [PubMed]

186. Bange, J.; Prechtl, D.; Cheburkin, Y.; Specht, K.; Harbeck, N.; Schmitt, M.; Knyazeva, T.; Müller, S.; Gärtner, S.; Sures, I.; et al. Cancer progression and tumor cell motility are associated with the FGFR4 Arg388 allele. Cancer Res. 2002, 62, 840-847. [PubMed]

187. Quintanal-Villalonga, Á.; Ojeda-Márquez, L.; Marrugal, Á.; Yagüe, P.; Ponce-Aix, S.; Salinas, A.; Carnero, A.; Ferrer, I.; MolinaPinelo, S.; Paz-Ares, L. The FGFR4-388arg Variant Promotes Lung Cancer Progression by N-Cadherin Induction. Sci. Rep. 2018, 8, 2394. [CrossRef] [PubMed]

188. Whittle, S.B.; Reyes, S.; Du, M.; Gireud, M.; Zhang, L.; Woodfield, S.E.; Ittmann, M.; Scheurer, M.E.; Bean, A.J.; Zage, P.E. A polymorphism in the FGFR4 gene is associated with risk of neuroblastoma and altered receptor degradation. J. Pediatr. Hematol. Oncol. 2016, 38, 131-138. [CrossRef]

189. Sugiyama, N.; Varjosalo, M.; Meller, P.; Lohi, J.; Chan, K.M.; Zhou, Z.; Alitalo, K.; Taipale, J.; Keski-Oja, J.; Lehti, K. FGF receptor-4 (FGFR4) polymorphism acts as an activity switch of a membrane type 1 matrix metalloproteinase-FGFR4 complex. Proc. Natl. Acad. Sci. USA 2010, 107, 15786-15791. [CrossRef] [PubMed]

190. Thakur, V.; Zhang, K.; Savadelis, A.; Zmina, P.; Aguila, B.; Welford, S.M.; Abdul-Karim, F.; Bonk, K.W.; Keri, R.A.; Bedogni, B. The membrane tethered matrix metalloproteinase MT1-MMP triggers an outside-in DNA damage response that impacts chemo- and radiotherapy responses of breast cancer. Cancer Lett. 2019, 443, 115-124. [CrossRef]

191. Udayakumar, T.S.; Nagle, R.B.; Bowden, G.T. Fibroblast Growth Factor-I Transcriptionally Induces Membrane Type-I Matrix Metalloproteinase Expression in Prostate Carcinoma Cell Line. Prostate 2004, 58, 66-75. [CrossRef]

192. Nomura, S.; Yoshitomi, H.; Takano, S.; Shida, T.; Kobayashi, S.; Ohtsuka, M.; Kimura, F.; Shimizu, H.; Yoshidome, H.; Kato, A.; et al. FGF10/FGFR2 signal induces cell migration and invasion in pancreatic cancer. Br. J. Cancer 2008, 99, 305-313. [CrossRef] [PubMed]

193. Tassone, E.; Valacca, C.; Mignatti, P. Membrane-type 1 matrix metalloproteinase downregulates fibroblast growth factor-2 binding to the cell surface and intracellular signaling. J. Cell. Physiol. 2015, 230, 366-377. [CrossRef]

194. Luo, H.; Zhang, T.; Cheng, P.; Li, D.; Ogorodniitchouk, O.; Lahmamssi, C.; Wang, G.; Lan, M. Therapeutic implications of fibroblast growth factor receptor inhibitors in a combination regimen for solid tumors (Review). Oncol. Lett. 2020, 20, $2525-2536$. [CrossRef] [PubMed]

195. Repetto, M.; Crimini, E.; Giugliano, F.; Morganti, S.; Belli, C.; Curigliano, G. Selective FGFR/FGF pathway inhibitors: Inhibition strategies, clinical activities, resistance mutations, and future directions. Expert Rev. Clin. Pharmacol. 2021, 14, 1233-1252. [CrossRef]

196. Yue, S.; Li, Y.; Chen, X.; Wang, J.; Li, M.; Chen, Y.; Wu, D. FGFR-TKI resistance in cancer: Current status and perspectives. J. Hematol. Oncol. 2021, 14, 23. [CrossRef] [PubMed]

197. Porta, R.; Borea, R.; Coelho, A.; Khan, S.; Araújo, A.; Reclusa, P.; Franchina, T.; Van Der Steen, N.; Van Dam, P.; Ferri, J.; et al. FGFR a promising druggable target in cancer: Molecular biology and new drugs. Crit. Rev. Oncol. Hematol. 2017, 113, $256-267$. [CrossRef] [PubMed]

198. Gavine, P.R.; Mooney, L.; Kilgour, E.; Thomas, A.P.; Al-Kadhimi, K.; Beck, S.; Rooney, C.; Coleman, T.; Baker, D.; Mellor, M.J.; et al. AZD4547: An orally bioavailable, potent, and selective inhibitor of the fibroblast growth factor receptor tyrosine kinase family. Cancer Res. 2012, 72, 2045-2056. [CrossRef]

199. Chua, V.; Orloff, M.; Teh, J.L.; Sugase, T.; Liao, C.; Purwin, T.J.; Lam, B.Q.; Terai, M.; Ambrosini, G.; Carvajal, R.D.; et al. Stromal fibroblast growth factor 2 reduces the efficacy of bromodomain inhibitors in uveal melanoma. EMBO Mol. Med. 2019, 11, e9081. [CrossRef] [PubMed]

200. Saito, S.; Morishima, K.; Ui, T.; Hoshino, H.; Matsubara, D.; Ishikawa, S.; Aburatani, H.; Fukayama, M.; Hosoya, Y.; Sata, N.; et al. The role of HGF/MET and FGF/FGFR in fibroblast-derived growth stimulation and lapatinib-resistance of esophageal squamous cell carcinoma. BMC Cancer 2015, 15, 82. [CrossRef] [PubMed]

201. Pardo, O.E.; Latigo, J.; Jeffery, R.E.; Nye, E.; Poulsom, R.; Spencer-Dene, B.; Lemoine, N.R.; Stamp, G.W.; Aboagye, E.O.; Seckl, M.J. The fibroblast growth factor receptor inhibitor PD173074 blocks small cell lung cancer growth in vitro and in vivo. Cancer Res. 2009, 69, 8645-8651. [CrossRef] [PubMed]

202. Byron, S.A.; Loch, D.C.; Pollock, P.M. Fibroblast growth factor receptor inhibition synergizes with paclitaxel and doxorubicin in endometrial cancer cells. Int. J. Gynecol. Cancer 2012, 22, 1517-1526. [CrossRef]

203. Campbell, T.M.; Castro, M.A.A.; de Oliveira, K.G.; Ponder, B.A.J.; Meyer, K.B. Era binding by transcription factors NFIB and YBX1 enables FGFR2 signaling to modulate estrogen responsiveness in breast cancer. Cancer Res. 2018, 78, 410-421. [CrossRef] [PubMed] 
204. Patel, A.; Tiwari, A.K.; Chufan, E.E.; Sodani, K.; Anreddy, N.; Singh, S.; Ambudkar, S.V.; Stephani, R.; Chen, Z.S. PD173074, a selective FGFR inhibitor, reverses ABCB1-mediated drug resistance in cancer cells. Cancer Chemother. Pharmacol. 2013, 72, 189-199. [CrossRef]

205. Anreddy, N.; Patel, A.; Sodani, K.; Kathawala, R.J.; Chen, E.P.; Wurpel, J.N.D.; Chen, Z.-S. PD173074, a selective FGFR inhibitor, reverses MRP7 (ABCC10)-mediated MDR. Acta Pharm. Sin. B 2014, 4, 202-207. [CrossRef] [PubMed]

206. Wu, C.P.; Hung, T.H.; Hsiao, S.H.; Huang, Y.H.; Hung, L.C.; Yu, Y.J.; Chang, Y.T.; Wang, S.P.; Wu, Y.S. Erdafitinib resensitizes ABCB1-overexpressing multidrug-resistant cancer cells to cytotoxic anticancer drugs. Cancers 2020, 12, 1366. [CrossRef]

207. Feng, W.; Zhang, M.; Wu, Z.X.; Wang, J.Q.; Dong, X.D.; Yang, Y.; Teng, Q.X.; Chen, X.Y.; Cui, Q.; Yang, D.H. Erdafitinib Antagonizes ABCB1-Mediated Multidrug Resistance in Cancer Cells. Front. Oncol. 2020, 10, 9-11. [CrossRef] [PubMed]

208. Cha, H.J.; Choi, J.H.; Park, I.C.; Kim, C.H.; An, S.K.; Kim, T.J.; Lee, J.H. Selective FGFR inhibitor BGJ398 inhibits phosphorylation of AKT and STAT3 and induces cytotoxicity in sphere-cultured ovarian cancer cells. Int. J. Oncol. 2017, 50, 1279-1288. [CrossRef] [PubMed]

209. Lamberti, D.; Cristinziano, G.; Porru, M.; Leonetti, C.; Egan, J.B.; Shi, C.X.; Buglioni, S.; Amoreo, C.A.; Castellani, L.; Borad, M.J.; et al. HSP90 Inhibition Drives Degradation of FGFR2 Fusion Proteins: Implications for Treatment of Cholangiocarcinoma. Hepatology 2019, 69, 131-142. [CrossRef] [PubMed]

210. Wang, Y.; Ding, X.; Wang, S.; Moser, C.D.; Shaleh, H.M.; Mohamed, E.A.; Chaiteerakij, R.; Allotey, L.K.; Chen, G.; Miyabe, K.; et al. Antitumor effect of FGFR inhibitors on a novel cholangiocarcinoma patient derived xenograft mouse model endogenously expressing an FGFR2-CCDC6 fusion protein. Cancer Lett. 2016, 380, 163-173. [CrossRef] [PubMed]

211. Tyulyandina, A.; Harrison, D.; Yin, W.; Stepanova, E.; Kochenkov, D.; Solomko, E.; Peretolchina, N.; Daeyaert, F.; Joos, J.B.; Van Aken, K.; et al. Alofanib, an allosteric FGFR2 inhibitor, has potent effects on ovarian cancer growth in preclinical studies. Investig. New Drugs 2017, 35, 127-133. [CrossRef]

212. Sergei, B.; Pavel, D.; Aigul, G.; Firyuza, B.; Ilmira, N.; Ilshat, M.; Aida, A.; Refat, K.; Natalia, A.; Elena, S.; et al. Inhibition of FGFR2-signaling attenuates a homology-mediated dna repair in gist and sensitizes them to DNA-topoisomerase II inhibitors. Int. J. Mol. Sci. 2020, 21, 352. [CrossRef] [PubMed]

213. Raoof, S.; Mulford, I.J.; Frisco-Cabanos, H.; Nangia, V.; Timonina, D.; Labrot, E.; Hafeez, N.; Bilton, S.J.; Drier, Y.; Ji, F.; et al. Targeting FGFR overcomes EMT-mediated resistance in EGFR mutant non-small cell lung cancer. Oncogene 2019, 38, 6399-6413. [CrossRef]

214. Qiu, H.; Yashiro, M.; Zhang, X.; Miwa, A.; Hirakawa, K. A FGFR2 inhibitor, Ki23057, enhances the chemosensitivity of drugresistant gastric cancer cells. Cancer Lett. 2011, 307, 47-52. [CrossRef]

215. Katoh, M. Fibroblast growth factor receptors as treatment targets in clinical oncology. Nat. Rev. Clin. Oncol. 2019, 16, 105-122. [CrossRef] [PubMed]

216. Tolcher, A.W.; Papadopoulos, K.P.; Patnaik, A.; Wilson, K.; Thayer, S.; Zanghi, J.; Gemo, A.T.; Kavanaugh, W.M.; Keer, H.N.; LoRusso, P.M. A phase I, first in human study of FP-1039 (GSK3052230), a novel FGF ligand trap, in patients with advanced solid tumors. Ann. Oncol. 2016, 27, 526-532. [CrossRef]

217. Presta, M.; Chiodelli, P.; Giacomini, A.; Rusnati, M.; Ronca, R. Fibroblast growth factors (FGFs) in cancer: FGF traps as a new therapeutic approach. Pharmacol. Ther. 2017, 179, 171-187. [CrossRef]

218. Zhang, Y.; Song, S.; Yang, F.; Au, J.L.S.; Guillaume Wientjes, M. Nontoxic doses of suramin enhance activity of doxorubicin in prostate tumors. J. Pharmacol. Exp. Ther. 2001, 299, 426-433.

219. Wu, Z.S.; Liu, C.F.; Fu, B.; Chou, R.H.; Yu, C. Suramin blocks interaction between human FGF1 and FGFR2 D2 domain and reduces downstream signaling activity. Biochem. Biophys. Res. Commun. 2016, 477, 861-867. [CrossRef] [PubMed]

220. Villalona-Calero, M.A.; Otterson, G.A.; Wientjes, M.G.; Weber, F.; Bekaii-Saab, T.; Young, D.; Murgo, A.J.; Jensen, R.; Yeh, T.K.; Wei, Y.; et al. Noncytotoxic suramin as a chemosensitizer in patients with advanced non-small-cell lung cancer: A phase II study. Ann. Oncol. 2008, 19, 1903-1909. [CrossRef] [PubMed]

221. Magee, P.; Shi, L.; Garofalo, M. Role of microRNAs in chemoresistance. Ann. Transl. Med. 2015, 3, 332. [CrossRef] [PubMed]

222. Qin, W.; Xie, W.; Yang, X.; Xia, N.; Yang, K. Inhibiting microRNA-449 Attenuates Cisplatin-Induced Injury in NRK-52E Cells Possibly via Regulating the SIRT1/P53/BAX Pathway. Med. Sci. Monit. 2016, 22, 818-823. [CrossRef]

223. Hu, Y.; Qiu, Y.; Yagüe, E.; Ji, W.; Liu, J.; Zhang, J. MiRNA-205 targets VEGFA and FGF2 and regulates resistance to chemotherapeutics in breast cancer. Cell Death Dis. 2016, 7, e2291. [CrossRef] [PubMed]

224. Paik, P.K.; Shen, R.; Berger, M.F.; Ferry, D.; Soria, J.C.; Mathewson, A.; Rooney, C.; Smith, N.R.; Cullberg, M.; Kilgour, E.; et al. A phase Ib open-label multicenter study of AZD4547 in patients with advanced squamous cell lung cancers. Clin. Cancer Res. 2017, 23, 5366-5373. [CrossRef] [PubMed]

225. Nogova, L.; Sequist, L.V.; Garcia, J.M.P.; Andre, F.; Delord, J.P.; Hidalgo, M.; Schellens, J.H.M.; Cassier, P.A.; Camidge, D.R.; Schuler, M.; et al. Evaluation of BGJ398, a Fibroblast growth factor receptor 1-3 kinase inhibitor, in patientswith advanced solid tumors harboring genetic alterations in fibroblast growth factor receptors: Results of a global phase I, dose-escalation and dose-expansion stud. J. Clin. Oncol. 2017, 35, 157-165. [CrossRef] [PubMed]

226. Byron, S.A.; Chen, H.; Wortmann, A.; Loch, D.; Gartside, M.G.; Dehkhoda, F.; Blais, S.P.; Neubert, T.A.; Mohammadi, M.; Pollock, P.M. The N550K/H mutations in FGFR2 confer differential resistance to PD173074, dovitinib, and ponatinib ATP-competitive inhibitors. Neoplasia 2013, 15, 975-988. [CrossRef] 
227. Chell, V.; Balmanno, K.; Little, A.S.; Wilson, M.; Andrews, S.; Blockley, L.; Hampson, M.; Gavine, P.R.; Cook, S.J. Tumour cell responses to new fibroblast growth factor receptor tyrosine kinase inhibitors and identification of a gatekeeper mutation in FGFR3 as a mechanism of acquired resistance. Oncogene 2013, 32, 3059-3070. [CrossRef]

228. Wu, C.; Chen, X.; Chen, D.; Xia, Q.; Liu, Z.; Li, F.; Yan, Y.; Cai, Y. Insight into ponatinib resistance mechanisms in rhabdomyosarcoma caused by the mutations in FGFR4 tyrosine kinase using molecular modeling strategies. Int. J. Biol. Macromol. 2019, 135, 294-302. [CrossRef]

229. Ryan, M.R.; Sohl, C.D.; Luo, B.; Anderson, K.S. The FGFR1 V561M gatekeeper mutation drives AZD4547 resistance through STAT3 activation and EMT. Mol. Cancer Res. 2019, 17, 532-543. [CrossRef]

230. Jiang, K.; Tang, X.; Guo, J.; He, R.; Chan, S.; Song, X.; Tu, Z.; Wang, Y.; Ren, X.; Ding, K.; et al. GZD824 overcomes FGFR1-V561F/M mutant resistance in vitro and in vivo. Cancer Med. 2021, 10, 4874-4884. [CrossRef] [PubMed]

231. Goyal, L.; Saha, S.K.; Liu, L.Y.; Siravegna, G.; Leshchiner, I.; Ahronian, L.G.; Lennerz, J.K.; Vu, P.; Deshpande, V.; Kambadakone, A.; et al. Polyclonal Secondary FGFR2 Mutations Drive Acquired Resistance to FGFR Inhibition in Patients with FGFR2 Fusion-Positive Cholangiocarcinoma. Cancer Discov. 2017, 7, 252-263. [CrossRef] [PubMed]

232. Krook, M.A.; Bonneville, R.; Chen, H.Z.; Reeser, J.W.; Wing, M.R.; Martin, D.M.; Smith, A.M.; Dao, T.; Samorodnitsky, E.; Paruchuri, A.; et al. Tumor heterogeneity and acquired drug resistance in FGFR2-fusion-positive cholangiocarcinoma through rapid research autopsy. Cold Spring Harb. Mol. Case Stud. 2019, 5, a004002. [CrossRef] [PubMed]

233. Goyal, L.; Shi, L.; Liu, L.Y.; de la Cruz, F.F.; Lennerz, J.K.; Raghavan, S.; Leschiner, I.; Elagina, L.; Siravegna, G.; Ng, R.W.S.; et al. TAS-120 overcomes resistance to atp-competitive FGFR inhibitors in patients with FGFR2 fusion-positive intrahepatic cholangiocarcinoma. Cancer Discov. 2019, 9, 1064-1079. [CrossRef] [PubMed]

234. Kim, S.Y.; Ahn, T.; Bang, H.; Ham, J.S.; Kim, J.; Kim, S.T.; Jang, J.; Shim, M.; Kang, S.Y.; Park, S.H.; et al. Acquired resistance to LY2874455 in FGFR2-amplified gastric cancer through an emergence of novel FGFR2-ACSL5 fusion. Oncotarget 2017, 8, 15014-15022. [CrossRef] [PubMed]

235. Latko, M.; Czyrek, A.; Porębska, N.; Kucińska, M.; Otlewski, J.; Zakrzewska, M.; Opaliński, Ł. Cross-Talk between Fibroblast Growth Factor Receptors and Other Cell Surface Proteins. Cells 2019, 8, 455. [CrossRef]

236. Adachi, Y.; Watanabe, K.; Kita, K.; Kitai, H.; Kotani, H.; Sato, Y.; Inase, N.; Yano, S.; Ebi, H. Resistance mediated by alternative receptor tyrosine kinases in FGFR1-amplified lung cancer. Carcinogenesis 2017, 38, 1063-1072. [CrossRef] [PubMed]

237. Datta, J.; Damodaran, S.; Parks, H.; Ocrainiciuc, C.; Miya, J.; Yu, L.; Gardner, E.P.; Samorodnitsky, E.; Wing, M.R.; Bhatt, D.; et al. Akt Activation Mediates Acquired Resistance to Fibroblast Growth Factor Receptor Inhibitor BGJ398. Mol. Cancer Ther. 2017, 16, 614-624. [CrossRef]

238. Chang, J.; Wang, S.; Zhang, Z.; Liu, X.; Wu, Z.; Geng, R.; Ge, X.; Dai, C.; Liu, R.; Zhang, Q.; et al. Multiple receptor tyrosine kinase activation attenuates therapeutic efficacy of the fibroblast growth factor receptor 2 inhibitor AZD4547 in FGFR2 amplified gastric cancer. Oncotarget 2015, 6, 2009-2022. [CrossRef]

239. Prawira, A.; Le, T.B.U.; Ho, R.Z.W.; Huynh, H. Upregulation of the ErbB family by EZH2 in hepatocellular carcinoma confers resistance to FGFR inhibitor. J. Cancer Res. Clin. Oncol. 2021, 147, 2955-2968. [CrossRef]

240. Wang, J.; Mikse, O.; Liao, R.G.; Li, Y.; Tan, L.; Janne, P.A.; Gray, N.S.; Wong, K.K.; Hammerman, P.S. Ligand-associated ERBB2/3 activation confers acquired resistance to FGFR inhibition in FGFR3-dependent cancer cells. Oncogene 2014, 34, $2167-2177$. [CrossRef] [PubMed]

241. Xu, H.; Shen, J.; Xiang, J.; Li, H.; Li, B.; Zhang, T.; Zhang, L.; Mao, X.; Jian, H.; Shu, Y. Characterization of acquired receptor tyrosine-kinase fusions as mechanisms of resistance to EGFR tyrosine-kinase inhibitors. Cancer Manag. Res. 2019, 11, 6343-6351. [CrossRef] [PubMed]

242. Chen, R.; Li, D.; Zheng, M.; Chen, B.; Wei, T.; Wang, Y.; Li, M.; Huang, W.; Tong, Q.; Wang, Q.; et al. FGFRL1 affects chemoresistance of small-cell lung cancer by modulating the PI3K/Akt pathway via ENO1. J. Cell. Mol. Med. 2020, 24, $2123-2134$. [CrossRef] [PubMed]

243. Silva, P.N.; Altamentova, S.M.; Kilkenny, D.M.; Rocheleau, J.V. Fibroblast Growth Factor Receptor Like-1 (FGFRL1) interacts with SHP-1 phosphatase at insulin secretory granules and induces beta-cell ERK1/2 protein activation. J. Biol. Chem. 2013, 288, 17859-17870. [CrossRef] [PubMed]

244. Liu, Q.; Hu, S.; Li, X.; Yan, S.; Xing, S.; Li, J.; Tan, H. MiRNA-495 inhibits cell proliferation and invasion abilities in gastric cancer cells by down-regulation of FGFRL1. Int. J. Clin. Exp. Pathol. 2016, 9, 7867-7877.

245. Memarzadeh, S.; Cai, H.; Janzen, D.M.; Xin, L.; Lukacs, R.; Riedinger, M.; Zong, Y.; DeGendt, K.; Verhoeven, G.; Huang, J.; et al. Role of autonomous androgen receptor signaling in prostate cancer initiation is dichotomous and depends on the oncogenic signal. Proc. Natl. Acad. Sci. USA 2011, 108, 7962-7967. [CrossRef]

246. Fenig, E.; Livnat, T.; Sharkon-Polak, S.; Wasserman, L.; Beery, E.; Lilling, G.; Yahalom, J.; Wieder, R.; Nordenberg, J. Basic fibroblast growth factor potentiates cisplatinum-induced cytotoxicity in MCF-7 human breast cancer cells. J. Cancer Res. Clin. Oncol. 1999, 125, 556-562. [CrossRef]

247. Wang, Q.; Maloof, P.; Wang, H.; Fenig, E.; Stein, D.; Nichols, G.; Denny, T.N.; Yahalom, J.; Wieder, R. Basic Fibroblast Growth Factor Downregulates Bcl-2 and Promotes Apoptosis in MCF-7 Human Breast Cancer Cells. Exp. Cell Res. 1998, 238, $177-187$. [CrossRef]

248. Coleman, A.B.; Metz, M.Z.; Donohue, C.A.; Schwarz, R.E.; Kane, S.E. Chemosensitization by fibroblast growth factor-2 is not dependent upon proliferation, S-phase accumulation, or p53 status. Biochem. Pharmacol. 2002, 64, 1111-1123. [CrossRef] 
249. Im, Y.S.; Shin, H.K.; Kim, H.R.; Jeong, S.H.; Kim, S.R.; Kim, Y.M.; Lee, D.H.; Jeon, S.H.; Lee, H.W.; Choi, J.K. Enhanced cytotoxicity of 5-FU by bFGF through up-regulation of uridine phosphorylase 1. Mol. Cells 2009, 28, 119-124. [CrossRef]

250. Luo, Y.; Yang, C.; Lu, W.; Xie, R.; Jin, C.; Huang, P.; Wang, F.; McKeehan, W.L. Metabolic Regulator $\beta$ Klotho Interacts with Fibroblast Growth Factor Receptor 4 (FGFR4) to Induce Apoptosis and Inhibit Tumor Cell Proliferation. J. Biol. Chem. 2010, 285, 30069-30078. [CrossRef]

251. Liu, Z.; Zhang, H.; Ding, S.; Qi, S.; Liu, S.; Sun, D.; Dong, W.; Yin, L.; Li, M.; Zhao, X.; et al. ßklotho inhibits androgen/androgen receptor-associated epithelial-mesenchymal transition in prostate cancer through inactivation of ERK1/2 signaling. Oncol. Rep. 2018, 40, 217-225. [CrossRef]

252. Massabeau, C.; Sigal-Zafrani, B.; Belin, L.; Savignoni, A.; Richardson, M.; Kirova, Y.M.; Cohen-Jonathan-Moyal, E.; MégninChanet, F.; Hall, J.; Fourquet, A. The fibroblast growth factor receptor 1 (FGFR1), a marker of response to chemoradiotherapy in breast cancer? Breast Cancer Res. Treat. 2012, 134, 259-266. [CrossRef]

253. Turkowski, K.; Herzberg, F.; Günther, S.; Brunn, D.; Weigert, A.; Meister, M.; Muley, T.; Kriegsmann, M.; Schneider, M.A.; Winter, H.; et al. Fibroblast Growth Factor-14 Acts as Tumor Suppressor in Lung Adenocarcinomas. Cells 2020, 9, 1755. [CrossRef]

254. Sochacka, M.; Opalinski, L.; Szymczyk, J.; Zimoch, M.B.; Czyrek, A.; Krowarsch, D.; Otlewski, J.; Zakrzewska, M. FHF1 is a bona fide fibroblast growth factor that activates cellular signaling in FGFR-dependent manner. Cell Commun. Signal. 2020, 18, 69. [CrossRef] [PubMed]

255. Johannes, L.; Jacob, R.; Leffler, H. Galectins at a glance. J. Cell Sci. 2018, 131, jcs208884. [CrossRef] [PubMed]

256. Navarro, P.; Martínez-Bosch, N.; Blidner, A.G.; Rabinovich, G.A. Impact of galectins in resistance to anticancer therapies. Clin. Cancer Res. 2020, 26, 6086-6101. [CrossRef]

257. Markowska, A.I.; Liu, F.T.; Panjwani, N. Galectin-3 is an important mediator of VEGF- and bFGF-mediated angiogenic response. J. Exp. Med. 2010, 207, 1981-1993. [CrossRef] [PubMed]

258. Kucińska, M.; Porȩbska, N.; Lampart, A.; Latko, M.; Knapik, A.; Zakrzewska, M.; Otlewski, J.; Opaliński, Ł. Differential regulation of fibroblast growth factor receptor 1 trafficking and function by extracellular galectins. Cell Commun. Signal. 2019, 17, 65. [CrossRef] [PubMed]

259. Porębska, N.; Poźniak, M.; Matynia, A.; Żukowska, D.; Zakrzewska, M.; Otlewski, J.; Opaliński, Ł. Galectins as modulators of receptor tyrosine kinases signaling in health and disease. Cytokine Growth Factor Rev. 2021, 60, 89-106. [CrossRef]

260. Liang, Q.; Wang, J.; Zhao, L.; Hou, J.; Hu, Y.; Shi, J. Recent advances of dual FGFR inhibitors as a novel therapy for cancer. Eur. J. Med. Chem. 2021, 214, 113205. [CrossRef]

261. Singleton, K.R.; Hinz, T.K.; Kleczko, E.K.; Marek, A.L.; Kwak, J.; Harp, T.; Kim, J.; Tan, A.C.; Heasley, L.E. Kinome RNAi screens reveal synergistic targeting of MTOR and FGFR1 Pathways for treatment of lung cancer and hnscc. Cancer Res. 2015, 75, 4398-4406. [CrossRef] [PubMed]

262. Packer, L.M.; Geng, X.; Bonazzi, V.F.; Ju, R.J.; Mahon, C.E.; Cummings, M.C.; Stephenson, S.A.; Pollock, P.M. PI3K inhibitors synergize with FGFR inhibitors to enhance antitumor responses in FGFR2mutant endometrial cancers. Mol. Cancer Ther. 2017, 16, 637-648. [CrossRef] [PubMed]

263. Dadone-Montaudié, B.; Laroche-Clary, A.; Mongis, A.; Chamorey, E.; Di Mauro, I.; Chaire, V.; Finetti, P.; Schiappa, R.; Le Loarer, F.; Birtwisle-Peyrottes, I.; et al. Novel Therapeutic Insights in Dedifferentiated Liposarcoma: A Role for FGFR and MDM2 Dual Targeting. Cancers 2020, 12, 3058. [CrossRef]

264. Guo, T.; Gu, C.; Li, B.; Xu, C. Dual inhibition of FGFR4 and BCL-xL inhibits multi-resistant ovarian cancer with BCL2L1 gain. Aging 2021, 13, 19750-19759. [CrossRef] [PubMed]

265. Lai, S.W.; Bamodu, O.A.; Chen, J.H.; Wu, A.T.; Lee, W.H.; Chao, T.Y.; Yeh, C.T. Targeted PARP Inhibition Combined with FGFR1 Blockade is Synthetically Lethal to Malignant Cells in Patients with Pancreatic Cancer. Cells 2020, 9, 911. [CrossRef]

266. Theocharopoulos, C.; Lialios, P.P.; Samarkos, M.; Gogas, H.; Ziogas, D.C. Antibody-drug conjugates: Functional principles and applications in oncology and beyond. Vaccines 2021, 9, 1111. [CrossRef]

267. Tong, J.T.W.; Harris, P.W.R.; Brimble, M.A.; Kavianinia, I. An Insight into FDA Approved Antibody-Drug Conjugates for Cancer Therapy. Molecules 2021, 26, 5847. [CrossRef]

268. Puthenveetil, S.; Musto, S.; Loganzo, F.; Tumey, L.N.; O’Donnell, C.J.; Graziani, E. Development of Solid-Phase Site-Specific Conjugation and Its Application toward Generation of Dual Labeled Antibody and Fab Drug Conjugates. Bioconjug. Chem. 2016, 27, 1030-1039. [CrossRef]

269. Świderska, K.W.; Szlachcic, A.; Opaliński, Ł.; Zakrzewska, M.; Otlewski, J. FGF2 dual warhead conjugate with monomethyl auristatin $\mathrm{E}$ and $\alpha$-amanitin displays a cytotoxic effect towards cancer cells overproducing FGF receptor 1. Int. J. Mol. Sci. 2018, 19, 2098. [CrossRef]

270. Schmid, S.L. Reciprocal regulation of signaling and endocytosis: Implications for the evolving cancer cell. J. Cell Biol. 2017, 216, 2623-2632. [CrossRef]

271. Mellman, I.; Yarden, Y. Endocytosis and cancer. Cold Spring Harb. Perspect. Biol. 2013, 5, a016949. [CrossRef] [PubMed]

272. Hammood, M.; Craig, A.W.; Leyton, J.V. Impact of endocytosis mechanisms for the receptors targeted by the currently approved adcs-A necessity for future adc research and development. Pharmaceuticals 2021, 14, 674. [CrossRef] 
273. Muley, H.; Fadó, R.; Rodríguez-Rodríguez, R.; Casals, N. Drug uptake-based chemoresistance in breast cancer treatment. Biochem. Pharmacol. 2020, 177, 113959. [CrossRef] [PubMed]

274. Pozniak, M.; Sokolowska-Wedzina, A.; Jastrzebski, K.; Szymczyk, J.; Porebska, N.; Krzyscik, M.A.; Zakrzewska, M.; Miaczynska, M.; Otlewski, J.; Opalinski, L. FGFR1 clustering with engineered tetravalent antibody improves the efficiency and modifies the mechanism of receptor internalization. Mol. Oncol. 2020, 14, 1998-2021. [CrossRef] [PubMed] 